\title{
Wind Flow Analysis on Simple Plan-Shaped Buildings
}

\author{
Basit Plan Formlu Binalarda Rüzgar Akış Analizi
}

Tuğba INAN GÜNAYDIN

\section{ABSTRACT}

Understanding the wind effects on the building is of great importance in the architectural field. The present study focuses on the analyse of various simple plan shaped buildings with different aspect ratios under various wind velocity to examine wind pressure distributions, and velocity distributions on and around the building. Therefore, the main evaluation criteria are plan shapes, building aspect ratios, storey height and wind velocity. With this aim, ANSYS Fluent 20.0 Computational Fluid Dynamics (CFD) software package program is used for the analysis. As a result of the study, it has been observed that the aspect ratios of width/height ratios (WR) and length/height (LR) ratios, building plan shape and wind velocity significantly affect the wind characteristics of the building. It has been observed that the change in the plan geometry did not have a significant effect on pressure coefficients on leeward surface. However, the change on the plan shape or variation in the aspect ratios have critical effects in the pressure coefficients on side surfaces. As the length of the building increased, the pressure values increased on the side surfaces. On the other hand, it has been noticed that building aspect ratios have significant impacts on pressure values. The most critical pressure values were observed on windward surface and on side surfaces in D4 model which has the greatest length ratio $(\mathrm{L} / \mathrm{H})$ of 6.0 .

Keywords: Building dimensions; building form; computational fluid dynamics (CFD); mean velocity magnitude; mean wind pressure.

Bina üzerine etkiyen rüzgar yüklerinin anlaşılması büyük önem taşımaktadır. Bu çalışma, rüzgar basınç dağılımlarını ve bina yüzeyindeki ve etrafındaki hız dağılımlarını incelemek için çeşitli rüzgar hızları altında farklı en-boy-yükseklik oranlarına sahip farklı basit plan geometrili binaların analizine odaklanmaktadır. Bu nedenle, ana değerlendirme kriterleri plan şekilleri, bina en-boy-yükseklik oranları, kat yüksekliği ve rüzgar hızıdır. Bu amaçla, ANSYS Fluent 20.0 Hesaplamalı Akışkanlar Dinamiği yazılım paket programı analiz için kullanılmaktadır. Çalışma sonucunda, genişlik/yükseklik oranları ve uzunluk/yükseklik oranlarının, bina planı şeklinin ve rüzgar hızının binanın rüzgar özelliklerini önemli ölçüde etkilediği görülmüş̧ür. Plan geometrisindeki değişimin, binanın rüzgar altı yüzeyindeki basınç katsayılarında önemli bir etkiye sahip olmadığı tespit edilmiştir. Ancak plan şeklindeki değişiklikler veya en-boy-yükseklik oranlarındaki farklılıklar, binanın yan yüzeylerindeki basınç katsayılarında kritik etkilere sahiptir. Bina uzunluğu arttıkça yan yüzeylerdeki basınç değerleri de artmıştır. Öte yandan, bina en-boy-yükseklik oranlarının basınç değerleri üzerinde önemli etkileri olduğu görülmüştür. En kritik basınç değerleri, uzunluk oranı 6.0 ile en yüksek uzunluk oranına sahip D4 kodlu modelin rüzgar üstü yüzeyinde ve yan yüzeylerinde görülmüştür.

Anahtar sözcükler: Bina boyutları; bina formu; hesaplamalı akışkanlar dinamiği; ortalama hı; ortalama rüzgar basıncı.

Department of Architecture, Niğde Ömer Halisdemir University Faculty of Architecture, Niğde, Turkey.

Article arrival date: July 06, 2020 - Accepted for publication: February 13, 2021

Correspondence: Tuğba INAN GÜNAYDIN. e-mail: tinan@ohu.edu.tr

○ 2021 Yıldız Teknik Üniversitesi Mimarlık Fakültesi - ๑ 2021 Yıldız Technical University, Faculty of Architecture 


\section{Introduction}

In recent years, with the rapid development of technology and great improvements in the standard of living, the needs of people in planning and living areas have greatly increased. The search for sustainable and durable buildings increasingly occupy a significant role in architecture. In national as well as international scale, this concern leads authorities to redefine building performance standards and demands for a revision of architectural thinking. In current society, to meet the needs of the rapidly increasing urban population, vertical architectural designs are widely used. Therefore, high-rise and tall buildings are gradually increasing in the built environment. This condition has not only changed the main wind field, but also created major effects on various aspects, such as built environment, urban climate, structural safety and thermal comfort (Zhao et al, 2017; Tong et al, 2016). In this respect, in architectural discourse, it is possible to notice a rising interest in analyzing wind load effects on buildings. CFD simulation is an effective method to realize this examination. Nowadays, wind energy is one of the significant energy sources of energy production.

Wind pressure is a significant design output parameter for analyzing the response of all facades to the wind loads. Wind pressure over windward facade especially on tall buildings, increases along building height because of an exponential increase in wind speed. Wind pressure depends on various factors such as building dimension and shapes, built environment and wind characteristics ( $\mathrm{Xu}$ et al. 2017; Mou et al, 2017; Zhao and He, 2017).

In order to receive the wind load effects on buildings, four methods have been discovered and followed from past to present. These are full-scale measurements, wind tunnel tests, theoretical studies and numerical simulation. However, these field studies are both time-consuming and costly.

In recent years, numerical approaches based on computational fluid dynamics (CFD) simulations are being commonly used by the engineers and architects for various wind studies such as determining wind loads on buildings and investigating wind flows in built area. Computational Fluid Dynamics (CFD) method is more economical and commonly accessible compared to the other methods. It provides solving the complex flow conditions via strong mathematical equations (Weerasuriya, 2013; Liu et al. 2020; Karadağ and Serteser, 2019; Şabanoğlu and Çağdaş, 2019). CFD have a significant role in every stage of building design. It can be used to achieve more reliable predictions related to parameters such as air flow, pressure, temperature, and similar.

Various studies have been conducted to investigate wind flow mechanism and to understand wind characteristics on buildings. Separation zones formed by wind interaction between the building and its immediate surroundings and various vortex groups have great importance in determining wind effects on buildings and taking into consideration appropriate design parameters. Vibrations with the growth of vortex that result from the wind interaction with building cause noise and damage (Gölbaşı et al, 2015). Becker et al. examined the flow field characteristics around threedimensional obstacles for various aspect ratios (wall length to wall width), in two different types of boundary layers in wind tunnel. They realized that the aspect ratio, the angle of attack, the Reynolds number, and the type of boundary layer affects the flow around the obstacle (Becker et al, 2002). Roberson and Crowe examined pressure distributions for turbulent flow condition in a building experimentally (Roberson and Crowe, 1978), while Ahmad and Kumar analyzed the effect of geometry on pressure for low-rise buildings (Ahmad and Kumar, 2002). Aygün and Başkaya investigated surface pressures on high-rise buildings occurred by the wind flow around the building (Aygün and Başkaya, 2003). Holmes et al. investigated wind loads in high, medium and low-rise buildings for 15 different regions in Asian Pacific region (Holmes et al, 2008). Mallick, Kumar and Patra investigated pressure coefficient over the surface of the models of varying configurations, corner curvature and angle of incidence between $0^{\circ}$ to $180^{\circ}$ at an interval of $30^{\circ}$ (Mallick et al., 2019). Bhattacharyya and Dalui investigated mean wind pressures on $E$ plan shaped tall building (Bhattacharyya and Dalui, 2018) Bairagi and Dalui examined pressure distribution around the square and setback tall buildings due to wind load. They designed models having single and double type setback at different elevations (Bairagi and Dalui, 2020). Fertelli and Balta investigated effects of wind load for the single and two building arrangements (Fertelli and Balta, 2017). Li et al. analyzed the characteristics of wind pressures on L-shaped tall buildings. The effects of geometric dimension on the wind pressures of L-shaped tall buildings were studied ( $\mathrm{Li}$ et al. 2020).

Pressure distribution information on building walls is significant for the investigation of wind loads. Pressure distributions from wind are affected by a wide variety of factors including flow conditions, urban environment, building geometry and wind direction (Montazeri and Blocken, 2013; Uematsu and Isyumov, 1999; Kim et al, 2012). Computational Fluid Dynamics (CFD) can be a valuable tool for determining average wind pressure coefficients on the building surface.

Wind is a significant architectural design component. However, there are very few studies on wind related behavior of buildings in the architectural field. This is often observed as an engineering problem. On the contrary, it 
is primarily an architectural design piece to be perceived. Therefore, understanding the behavior of buildings under wind loads is vital to develop problem-oriented solutions at every stage of the design phase. In recent years, numerical approaches based on computational fluid dynamics (CFD) simulations are being commonly used by the engineers and architects for various wind studies such as determining wind loads on buildings and investigating wind flows in built area.

Although the wind behavior of irregular building forms has been widely studied by many researchers, simple building forms have not been extensively investigated parametrically. Simple building forms are generally studied on the basis of a single parameter. This study is therefore designed to fill this gap by analyzing impacts of various parameters like building shapes, building height, building aspect ratios and wind velocity values on wind pressure distributions, and velocity distributions on and around the building. The main evaluation criteria are plan shapes, building aspect ratios and wind velocity.

With this aim, ANSYS Fluent 20.0 Computational Fluid Dynamics (CFD) software package program is used for the analysis. The results of CFD will provide comprehensive information regarding the wind effect on and around building to especially architects, architectural students and designers to use in their architectural design process as a design assistance tool.

\section{Building Aerodynamics}

The main subject of the building aerodynamics is investigating the airflow characteristics in or around the building. While regular air flows that run parallel to each other creates positive or compressive force on the windward surfaces of buildings, negative or suction force on both sides and leeward surface (Figure 1).

Variety in the pressure zones with orientation and the angle of the building with air flow is displayed on Figure 1. The air molecules hitting the wind above surface of the building stop as soon as they hit the surface and they change the direction licking the surface. After, they create the trace region behind the building by being detached from the surface of the breaking point and following side surfaces $(O k, 2010)$. If the wind hits perpendicular to the surface, suction forces on the other surfaces will not be higher than the compressive forces. However, if the wind comes to the surface at an angle the suction force can be more than twice the compressive force (Hasol, 1994). The air molecules already flow from the higher pressure zone (positive) to the lower pressure zone (negative).

The shape of the building affects pressure zones and levels created by the air flow around the building. When the narrow facade of the building positioned in the direction of

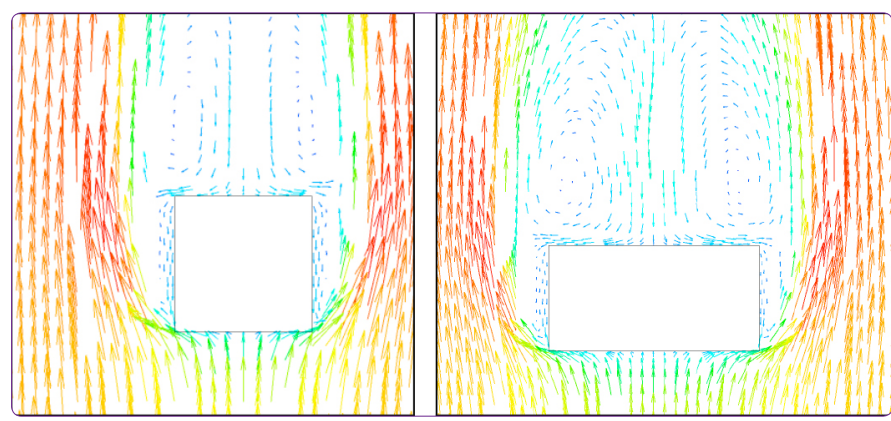

Figure 1. Air flows around the square and rectangular shaped buildings.

the wind, vigorous suction forces occurs on wide facades due to the negative pressure. When the wide facade of the building positioned in the direction of the wind, strong pushing effects occur on this facade with positive pressure. On the other hand, strong suction effects occur on the opposite facade with negative pressure (Figure 1).

Air molecules that are pushed by each other and have different wind velocity values create vortices. Air flows acting on from the ground with a gradient velocity profile creates skirting vortices from top to bottom on windward surface and different vortices on leeward facade and side surfaces. Therefore, different regions occur around the building due to the variety on wind direction and velocity (Hasol, 1994). This condition which depends on the building form, dimensions, and orientations can be enhanced with the studies to be done at the design stage.

\section{Numerical Simulation}

To design numerical models properly and provide reliable results, many factors should be considered, such as computational domain, meshing, boundary conditions, solver settings, boundary conditions and residual control. If parameters are not well considered, the analysis represent unrealistic results. In this study, Computational Fluid Dynamics (CFD) package of ANSYS FLUENT 20.0 is used for the analysis. CFD simulations comprise of three main part. These are computational domain, meshing and boundary conditions for inlet, outlet and other surfaces.

\section{Computational Domain and Meshing}

The size of the computational domain depends on the investigated model and the boundary conditions. Concerning computational domain of models, various guidelines have been suggested in the literature. Computational domain should be large enough to prevent reflection of fluid streams which may create exceptional pressure fields around the building model (Franke, 2006). Moreover, the distances around models should be long enough to provide the full development of the wind fields (He et al, 2014). Blocken analyzed urban physical factors and accuracy of CFD simulation and came up with 


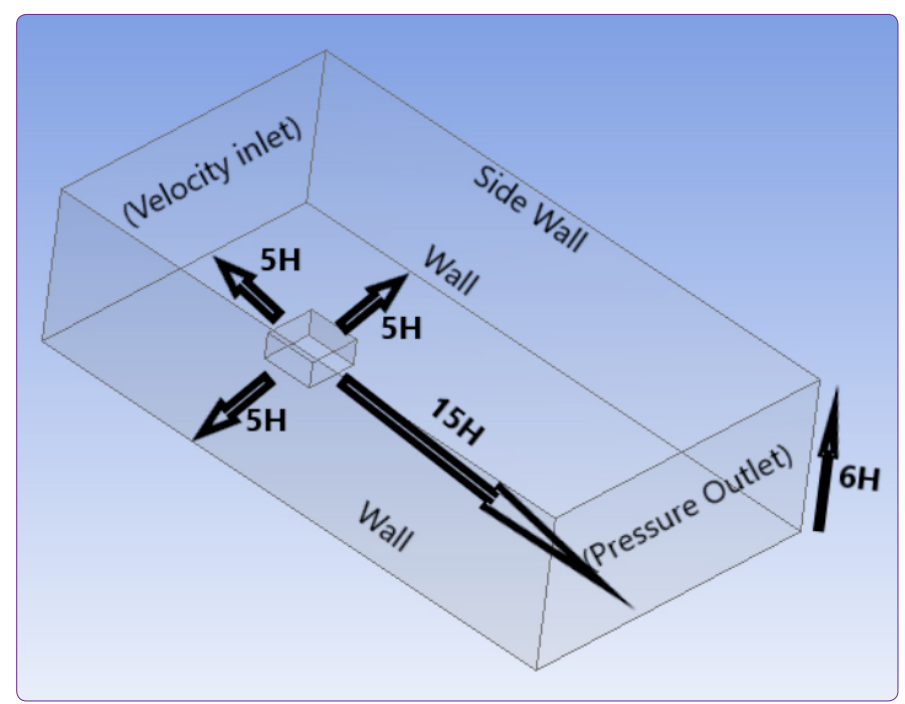

Figure 2. Computational Domain.

recommendations (Blocken, 2015).

Huang et al. represented the computational domains for tall buildings. In the study, single building models are investigated. For a single building model, the distance from the top of the building to the top of the computational domain and the distance from the inlet boundary should be at least $5 \mathrm{H}$, where $\mathrm{H}$ is the building height and lateral boundaries are 2 to 3 times $\mathrm{W}$, (where $\mathrm{W}$ is the built area width). Moreover, the outlet boundary is suggested, at least $15 \mathrm{H}$ behind the building (Franke, 2006). Tominaga et al. suggest $5 \mathrm{H}$ for the lateral boundary and inlet and at least $10 \mathrm{H}$ for the outlet boundary (Tominaga et al, 2008). It should be taken into consideration that if computational region is enlarged without it being properly based on the building surrounding, it display inaccurate results (Blocken et al, 2007). On accordance with these suggestions, the computational domain used for the analysis in this study is presented in Figure 2. While $5 \mathrm{H}$ is taken for the top, inlet and side walls, $15 \mathrm{H}$ is taken from the outlet in this study.

In meshing, grid quality and quantity ascertain computation time and results. In this study, a hexahedra grid type is chosen in the prediction of results. The minimum and maximum skewness values for $\mathrm{K} 1$ model are $5.21 \times 10-5$ and 0.5 respectively while it should be maximum 0.9. On the other hand, while orthogonal mesh quality should be minimum 0.1 , it is minimum 0.59 in this study. Model dimensions were reduced to $1 / 200$ scale to save computing time. The overall nodes and elements are 207435 and 195450 respectively for K1 model. Figure 2 represents the computational domain.

\section{Boundary Conditions}

Boundary conditions have a key role on the solutions inside the computational domain. Therefore, they should be chosen properly for the reliable results in a CFD simulation (Franke, 2006). The boundary conditions for inlet, outlet and the other surfaces should be ensured.

In this study, velocity inlet is used as inlet boundary with wind and turbulence quantities. Outlet is modelled as outflow boundary and side walls and top wall have symmetrical boundary conditions, and ground (bottom wall) has no-slip boundary condition. These boundary conditions are used during the numerical simulation in ANSYS FLUENT 20.0. Realizable $k-\varepsilon$ turbulent model is performed in the analysis.

This study was designed to analyze steady and incompressible flows. The outflow boundary conditions were selected in each model. Wind flow is accepted completely developed without any obstacle at the outlet of the computational domain. The wall boundary conditions were given related to the buildings and ground surface. The wall was accepted as stationery and with no-slip shear condition.

\section{Solution Method}

Numerical simulation was performed on the ANSYS FLUENT 20.0. To resolve the turbulence energy and diffusion rate terms, the Realizable k-epsilon turbulence model was used. The SIMPLE algorithm of Patankar was used to solve the pressure-velocity coupling (Patankar, 1980). Second-Order Upwind Scheme was used for the convection terms and the viscous terms of the governing equations. In the analyses, for all of the transport parameters, the convergence criterion has been defined as 10-7.

\section{Models}

One series of squared-shaped building models and two series of rectangular-shaped building models were designed to analyze the effect of simple building forms having different aspect ratios on their wind related features. In the study, a total of 9 models were analyzed. Among these models, the square form ones were coded with the letter $\mathrm{K}$ and the rectangular ones with the letter D. The model denoted as $\mathrm{K} 1$ has a height of $10 \mathrm{~m}$ and it is exposed to a wind velocity of $2 \mathrm{~m} / \mathrm{s}$. The model denoted as $\mathrm{K} 2$ has a height of $30 \mathrm{~m}$ and it is exposed to a wind velocity of $3 \mathrm{~m} / \mathrm{s}$. The model denoted as $\mathrm{K} 3$ has a height of $50 \mathrm{~m}$ and it is exposed to a wind velocity of $5 \mathrm{~m} / \mathrm{s}$. The model denoted as D1 has a height of $10 \mathrm{~m}$ with a size of $20 \mathrm{~m} \times 40$ $\mathrm{m}$ and it is exposed to a wind velocity of $2 \mathrm{~m} / \mathrm{s}$. The model denoted as D2 has a height of $30 \mathrm{~m}$ with a size of $20 \mathrm{~m} \times 40$ $\mathrm{m}$ and it is exposed to a wind velocity of $3 \mathrm{~m} / \mathrm{s}$. The model denoted as D3 has a height of $50 \mathrm{~m}$ with a size of $20 \mathrm{~m} \times 40$ $\mathrm{m}$ and it is exposed to a wind velocity of $5 \mathrm{~m} / \mathrm{s}$. The model denoted as D4 has a height of $10 \mathrm{~m}$ with a size of $20 \mathrm{~m} \times 60$ $\mathrm{m}$ and it is exposed to a wind velocity of $2 \mathrm{~m} / \mathrm{s}$. The model denoted as D5 has a height of $30 \mathrm{~m}$ with a size of $20 \mathrm{~m} \times 60$ $\mathrm{m}$ and it is exposed to a wind velocity of $3 \mathrm{~m} / \mathrm{s}$. The model 
denoted as D6 has a height of $50 \mathrm{~m}$ with a size of $20 \mathrm{~m} \times 60$ $\mathrm{m}$ and it is exposed to a wind velocity of $5 \mathrm{~m} / \mathrm{s}$.

Models could be categorized according to their dimensions including height-width (WR) ratio and height- length ratio, and other special information about the models is given in the Table 1 . The method of the study is summarized in Table 2. All assumptions used in the program are given in detail.

Table 1. Building Models

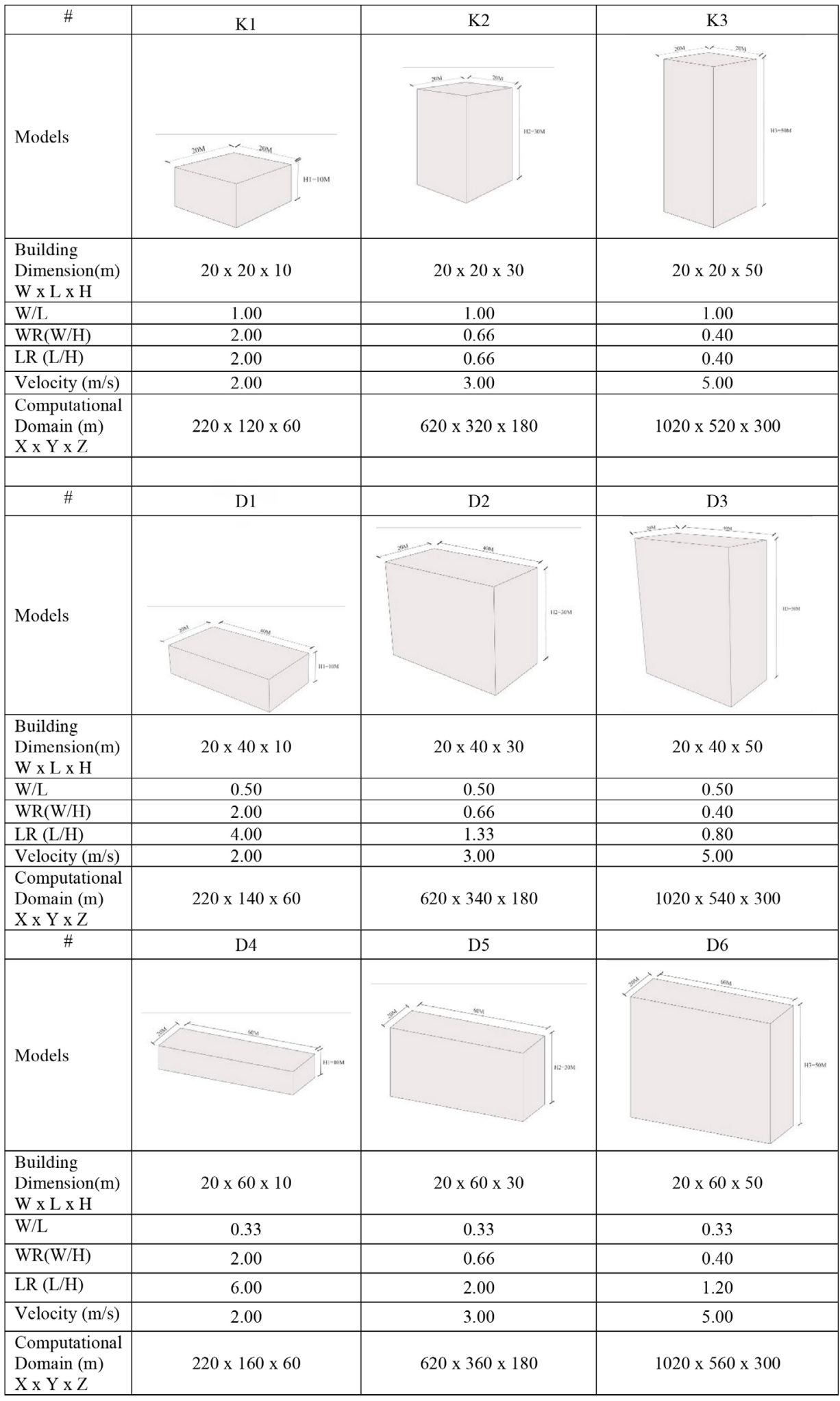


Table 2. Schematic description of the work

\begin{tabular}{|c|c|c|}
\hline \multirow{2}{*}{\multicolumn{2}{|c|}{$\begin{array}{l}\text { Creating Geometry in ANSYS-Workbench } \\
\text { - Square Plan Shapes } \\
\text { - Rectangular Plan Shapes }\end{array}$}} & \multirow[b]{2}{*}{$\begin{array}{l}\text { Generating Mesh } \\
\text { • Hexahedra grid type }\end{array}$} \\
\hline & & \\
\hline $\begin{array}{l}\quad \text { Defining of Surfaces } \\
\text { - Velocity Inlet (inlet boundary) } \\
\text { - Outlet (outflow boundary) } \\
\text { - Left side } \\
\text { - Right side } \\
\text { - Windward surface } \\
\text { - Leeward surface } \\
\text { - Top surface }\end{array}$ & \multicolumn{2}{|c|}{$\begin{array}{l}\text { Boundary Conditions } \\
\text { - Side walls and top surface have } \\
\text { symmetrical boundary conditions } \\
\text { - Bottom wall has no slip boundary } \\
\text { conditions } \\
\text { - Velocity inlet (inlet boundary) } \\
\text { - Outlet (Outflow Boundary) }\end{array}$} \\
\hline $\begin{array}{l}\text { Solution: } \\
\text { Computational Parameters } \\
\text { - Steady fully turbulent and three } \\
\text { dimensional flow } \\
\text { - Computational domain size: } \\
\text { - } 5 \mathrm{H} \text { from the top,inlet and side } \\
\text { walls, } 15 \mathrm{H} \text { from the outlet } \\
\text { - Turbulence model: } \\
\text { - Realizable k- } \varepsilon \text { turbulent model } \\
\text { - Algorithms \& Schemes: } \\
\text { - SIMPLE Algorithm } \\
\text { - Second Order Upwind Scheme } \\
\text { - Converge Criteria : } 10^{-7}\end{array}$ & & $\begin{array}{l}\text { Variables } \\
\text { - Building Height }(\mathrm{H}) \text { : } \\
\text { - } 10 \mathrm{~m}, 30 \mathrm{~m}, 50 \mathrm{~m} \\
\text { - Building aspect ratios: } \\
\text { - based on W/H and L/H } \\
\text { (W:width, L:Length of the } \\
\text { building) } \\
\text { - Wind Velocity: } \\
\text { - } 2 \mathrm{~m} / \mathrm{s}, 3 \mathrm{~m} / \mathrm{s}, 5 \mathrm{~m} / \mathrm{s} \\
\text { - Plan Shapes } \\
\text { - Square plan shapes } \\
\text { - Rectangular plan shapes }\end{array}$ \\
\hline \multicolumn{3}{|c|}{$\begin{array}{l}\text {-Wind pressure distributions on and around buildings } \\
\text { - Pressure coefficients at } \mathrm{H} / 3, \mathrm{H} / 2 \text { and } 2 \mathrm{H} / 3 \text { Height level } \\
\text { - Velocity distributions around buildings }\end{array}$} \\
\hline
\end{tabular}

\section{Discussions and Results}

To analyze wind pressure coefficients, wind pressure distributions and velocity distributions on and around the building for different simple plan shaped buildings under

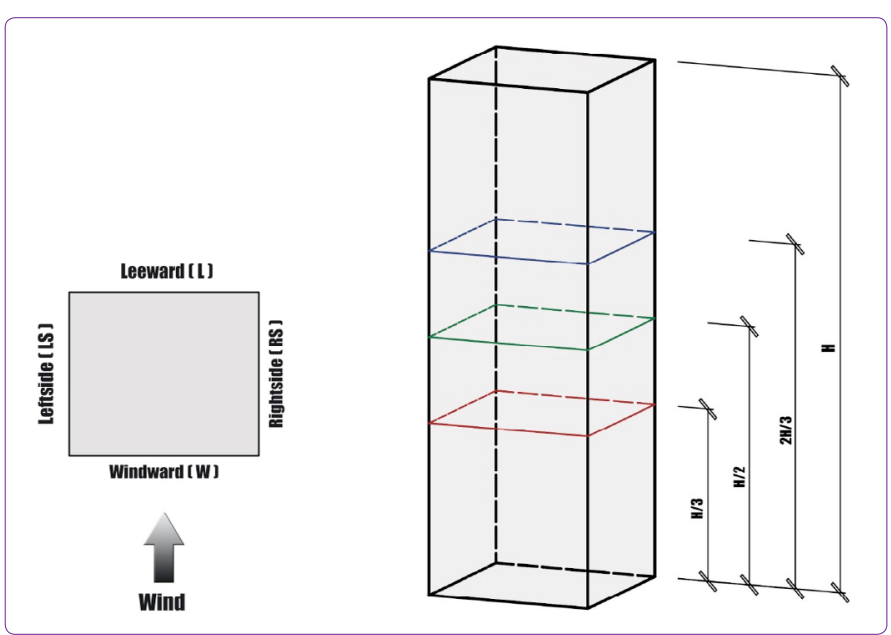

Figure 3. Model Surfaces and analyzed height levels. various wind velocity, ANSYS Fluent Computational Fluid Dynamics (CFD) software 20.0 package program is used. The results from the analysis is given comprehensively in this part. Windward (W), side walls (RS, LS) and leeward (L) are presented in Figure 3.

To examine wind characteristics of on and around various simple plan-shaped buildings with different building dimensions, wind pressure coefficients are sliced at the height of $2 H / 3, H / 2$ and $H / 3$, as shown in Figure 3. Apart from wind pressure on buildings, wind pressure distributions around buildings were also examined, at the height of $2 \mathrm{H} / 3$, $\mathrm{H} / 2$ and $\mathrm{H} / 3$ and $\mathrm{Y} / 2$ of computational domain.

\section{Pressure Distributions on Building Models}

To bring out wind characteristics on building surface, wind pressure distributions in all model surfaces are examined. The model denoted as K1 is a square plan shaped building with a height of $10 \mathrm{~m}$ and it is exposed to a wind velocity of $2 \mathrm{~m} / \mathrm{s}$. In $\mathrm{K} 1$ model, pressure coefficients take positive values on the windward surface due to the pushing forces and it was realized that these positive pressure values varied greatly. On windward surface, pressure values did not increase along the height. However, the surface area affected by the pressure was enlarged along the height on windward surface. Moreover, on windward surface the pressure values decreased at a height close to the model height. On the other hand, negative pressure values were observed on leeward and on both side surfaces (RS, LS). Besides, negative pressure values on the side surfaces are higher than negative pressure values on the leeward surface. Due to the flow leaving the upper edge of the windward surface of the building, a negative pressure region formed on the top of the building and on leeward surface. The flow leaving the front edge of the top detached from the leeward surface after holding the top surface again. The leeward wall is under the effect of suction due to the reverse flow occurring behind the building. Critical negative pressures occur at the region where flow leave the front edge of the top region. In K1 model, negative pressure values varied greatly at the top surface. The negative pressure values tend to decrease from windward to leeward on the top. Meanwhile, maximum positive pressure on the windward surface of $\mathrm{K} 1$ was 2.63 , absolute value of maximum negative pressure was 0.86 on leeward surface. On side surfaces, the absolute value of maximum negative pressure was 2.01 . It was 2.28 in the top surface (Figure 4).

The model denoted as $\mathrm{K} 2$ is a square plan shaped building with a height of $30 \mathrm{~m}$ and it is exposed to a wind velocity of $3 \mathrm{~m} / \mathrm{s}$. In K2 model, pressure coefficients take positive values on the windward surface and these positive pressure values varied greatly. On windward surface, pressure values did not increase generally along the height. However, it tends to increase from lower than 
the $H / 3$ height level to $H / 3$ height level. Besides, the surface area affected by the pressure was expanded along the height on windward surface. Moreover, on windward surface the pressure values decreased at a height close to the model height and on nearest to both side surfaces. This decreases can be more clearly observed on corner sides of the leeward surfaces. On the other hand, negative pressure values were varied greatly. Negative pressure values were observed on leeward and on both side surfaces (RS, LS). Besides, negative pressure values on the side surfaces are considerably higher than negative pressure values on the leeward surface. In K2 model, while maximum positive pressure on the windward surface was 5.75 , absolute value of maximum negative pressure was 1.44 on leeward surface. On side surfaces, the absolute value of maximum negative pressure was 3.91. In top surface, the absolute maximum negative pressure was 3.71 (Figure 5).

The model denoted as $\mathrm{K} 3$ is a square plan shaped building with a height of $50 \mathrm{~m}$ and it is exposed to a wind

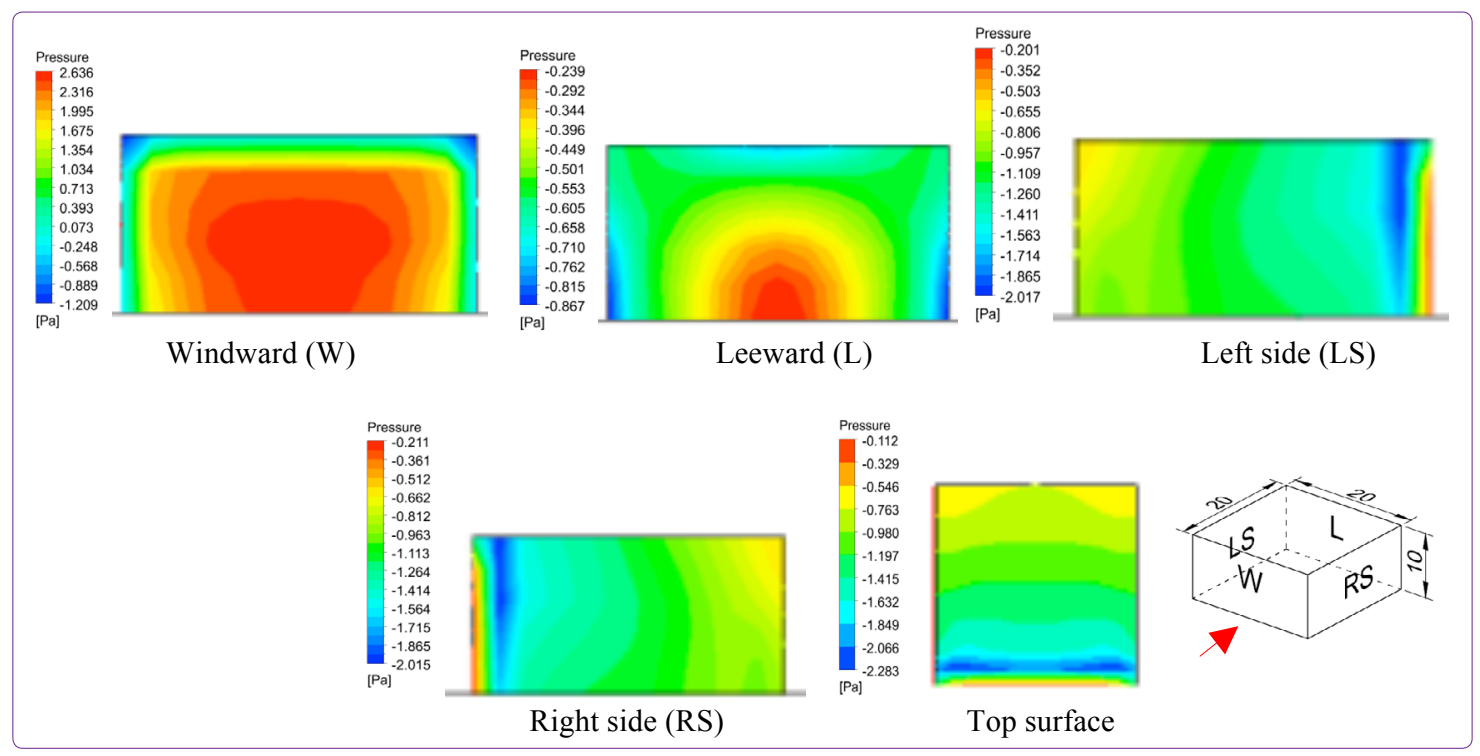

Figure 4. Wind pressure distributions on building surfaces for K1.

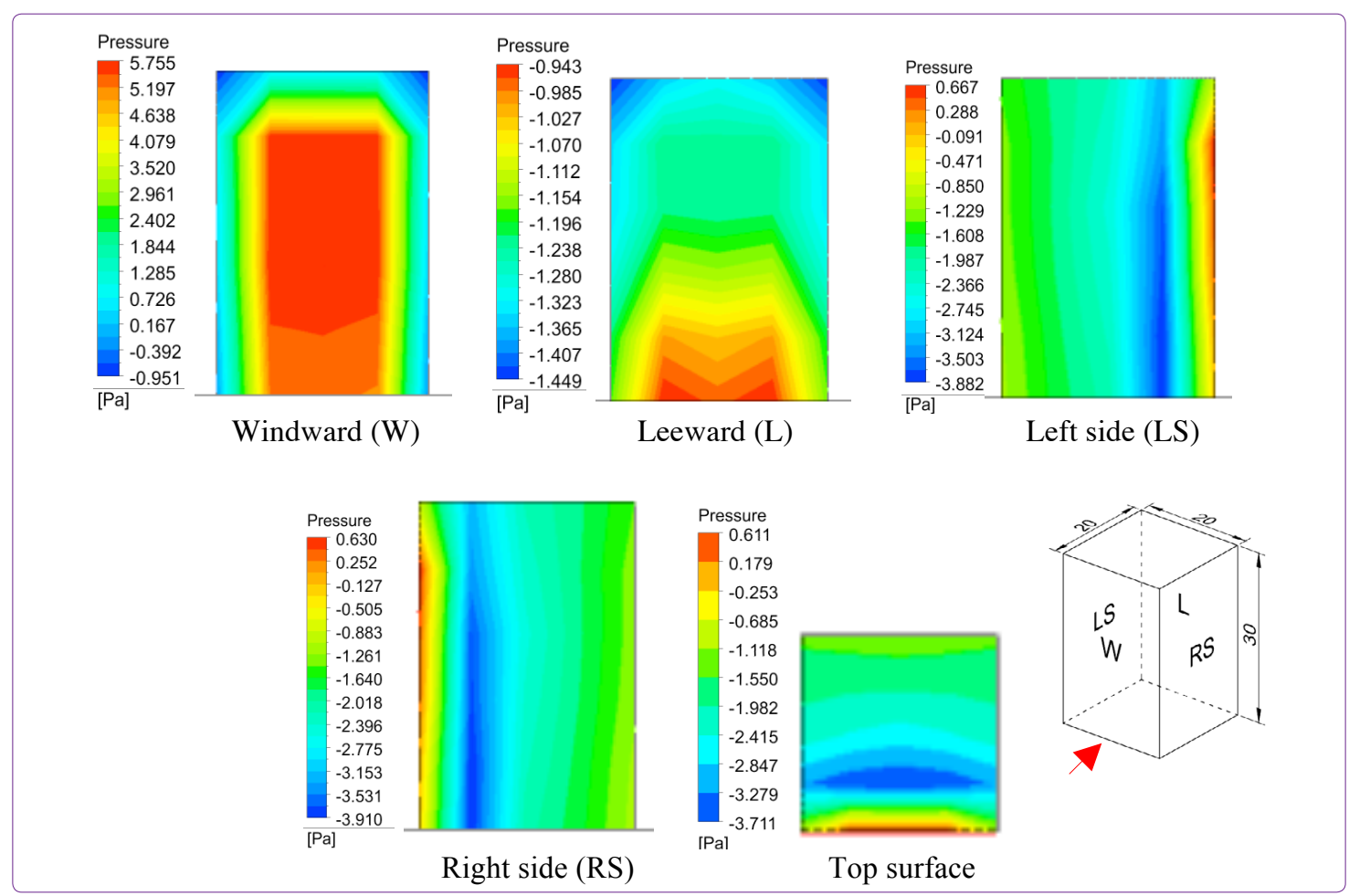

Figure 5. Wind pressure distributions on building surfaces for K2. 
velocity of $5 \mathrm{~m} / \mathrm{s}$. In $\mathrm{K} 3$ model, pressure coefficients take positive values on the windward surface and these positive pressure values varied greatly. On windward surface, pressure values did not increase generally along the height. However, it tends to increase from lower than the $\mathrm{H} / 3$ height level to $\mathrm{H} / 3$ height level. Besides, the surface area affected by the pressure was expanded along the height on windward surface. Moreover, on windward surface the positive pressure values decreased at a height close to the model height and on nearest to both side surfaces. These decreases can be more clearly observed nearest to the building height of the leeward surfaces. On the other hand, negative pressure values were varied greatly. Negative pressure values were observed on leeward and on both side surfaces (RS, LS). Besides, negative pressure values on the side surfaces are considerably higher than negative pressure values on the leeward surface. In K3 model, while maximum positive pressure on the windward surface was 15.53 , absolute value of maximum negative pressure was 6.39 on leeward surface. On side surfaces, the absolute value of maximum negative pressure was 12.06. In top surface, the absolute maximum negative pressure was 11.71 (Figure 6).

The model denoted as D1 is a rectangular plan shaped building with a height of $10 \mathrm{~m}$ and it is exposed to a wind velocity of $2 \mathrm{~m} / \mathrm{s}$. In D1 model, pressure coefficients take positive values on the windward surface and it was realized that these positive pressure values varied greatly. On windward surface, pressure values did not increase along the height. However, the surface area affected by the pressure was enlarged along the height on windward surface. Moreover, on windward surface the pressure values decreased at a height close to the model height and close to the side surfaces. On the other hand, negative pressure values were observed on leeward and on both side surfaces (RS, LS). Besides, negative pressure values on the side surfaces are higher than negative pressure values on the leeward surface. In D1 model, the negative pressure values tend to decrease from windward to leeward on the top. While maximum positive pressure on the windward surface of D1 was 2.78 , absolute value of maximum negative pressure was 1.21 on leeward surface. On side surfaces, the absolute value of maximum negative pressure was 2.34 . It was 2.28 in the top surface (Figure 7).

Side surfaces of D1 model (including RS and LS) were prone to expose to higher wind pressures than the square models. Therefore, it can be concluded that when windward surfaces were wider, the building expose to higher wind pressures.

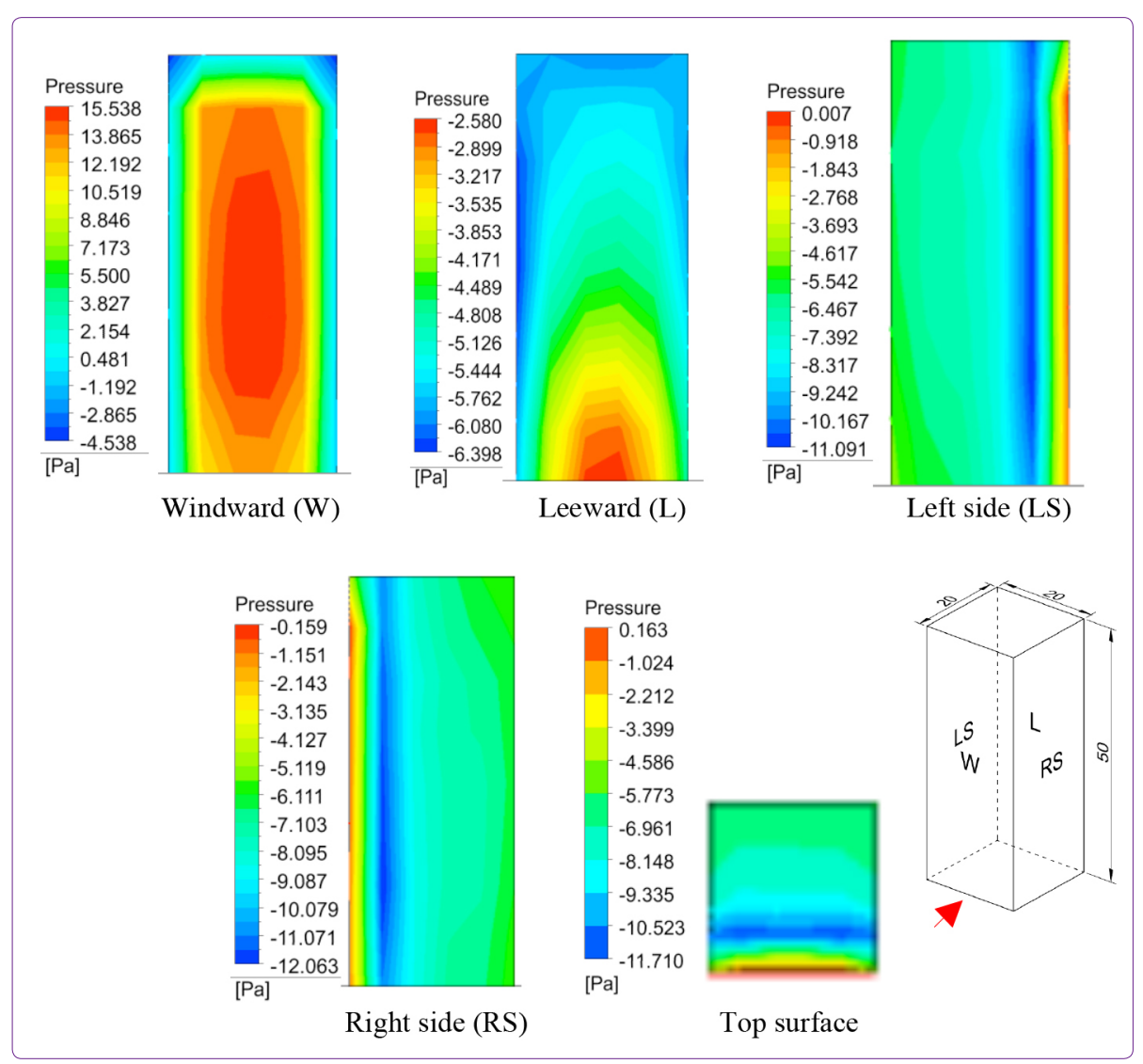

Figure 6. Wind pressure distributions on building surfaces for K3. 


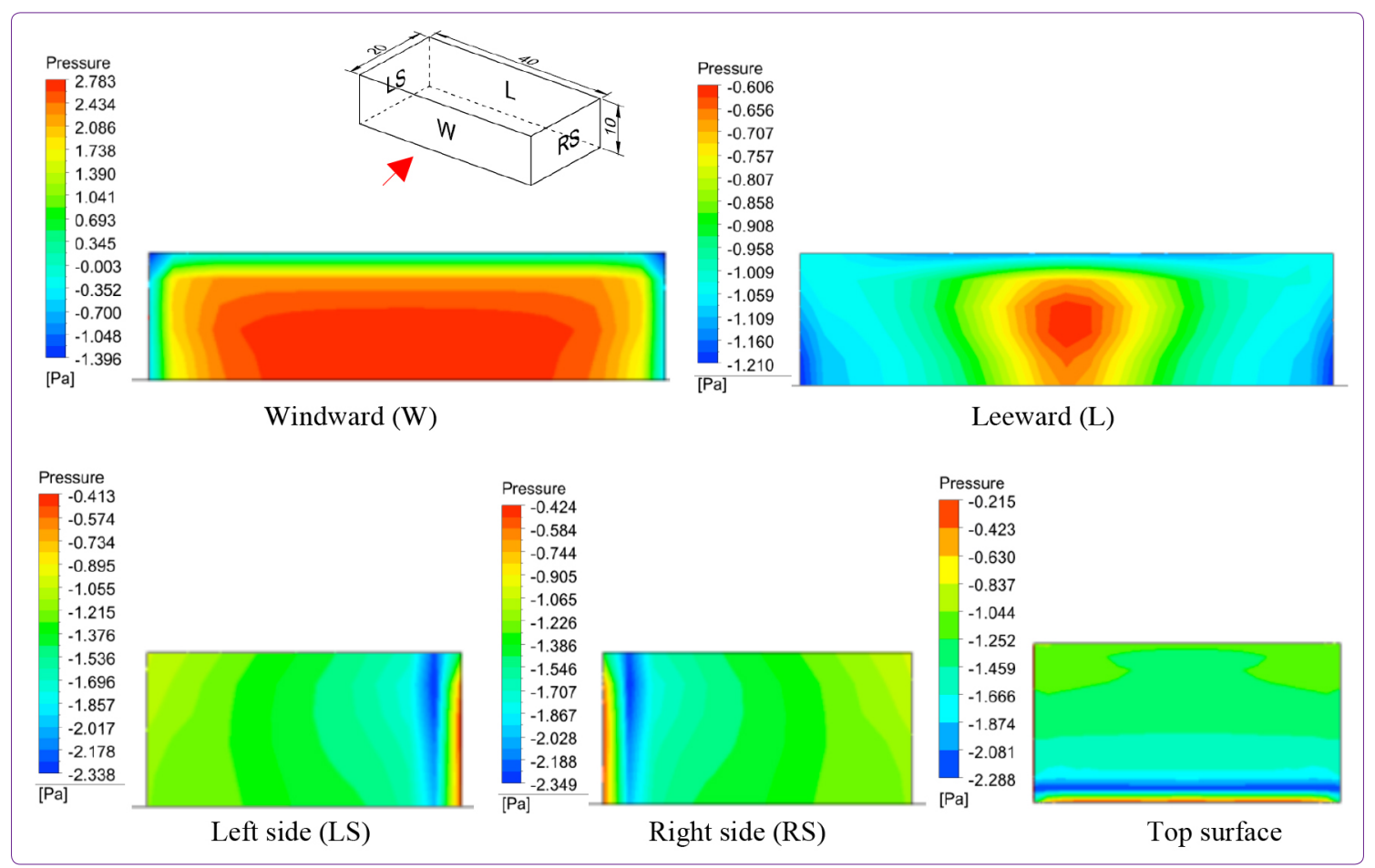

Figure 7. Wind pressure distributions on building surfaces for D1.

The model denoted as D2 is a rectangular plan shaped building with a height of $30 \mathrm{~m}$ and it is exposed to a wind velocity of $3 \mathrm{~m} / \mathrm{s}$. In D2 model, pressure coefficients take positive values on the windward surface and these positive pressure values varied greatly. On windward surface, pressure values did not increase generally along the height. However, it tends to increase from lower than nearly $\mathrm{H} / 3$ height level to $\mathrm{H} / 3$ height level. Besides, the surface area affected by the pressure was expanded along the height on windward surface. Moreover, on windward surface the pressure values decreased at a height close to the model height and on nearest to both side surfaces. These decreases can be more clearly observed close to the building height level on leeward surfaces. On the other hand, negative pressure values were varied greatly. Negative pressure values were observed on leeward and on both side surfaces (RS, LS). Negative pressure values on the side surfaces are seriously higher than negative pressure values on the leeward surface. In D2 model, while maximum positive pressure on the windward surface was 5.86, absolute value of maximum negative pressure was 2.03 on leeward surface. On side surfaces, the absolute value of maximum negative pressure was 3.70 . In top surface, the absolute maximum negative pressure was 3.74 (Figure 8 ).

The model denoted as D3 is a rectangular plan shaped building with a height of $50 \mathrm{~m}$ and it is exposed to a wind velocity of $5 \mathrm{~m} / \mathrm{s}$. In D3 model, pressure coefficients take positive values on the windward surface and these positive pressure values varied greatly. On windward surface, pressure values did not display a regular increase or decrease along the height of the building. Besides, the surface area affected by the pressure was expanded along the height on windward surface. Moreover, on windward surface the positive pressure values decreased at a height close to the model height and on nearest to both side surfaces. These decreases can be more clearly observed nearest to the building height of the leeward surfaces. On the other hand, negative pressure values were varied greatly. Negative pressure values were observed on leeward and on both side surfaces (RS, LS). Besides, negative pressure values on the side surfaces are considerably higher than negative pressure values on the leeward surface. In D3 model, while maximum positive pressure on the windward surface was 18.04, absolute value of maximum negative pressure was 9.31 on leeward surface. On side surfaces, the absolute value of maximum negative pressure was 17.74 . In top surface, the absolute maximum negative pressure was 16.85 (Figure 9).

The model denoted as D4 is a rectangular plan shaped building with a height of $10 \mathrm{~m}$ and it is exposed to a wind velocity of $2 \mathrm{~m} / \mathrm{s}$. In D4 model, pressure coefficients take positive values on the windward surface and it was noticed that these positive pressure values varied greatly. On windward surface, pressure values did not increase along the height. However, the surface area affected by the pressure was enlarged along the height and length on windward surface. Moreover, on windward surface the pressure values decreased at a height close to the model 


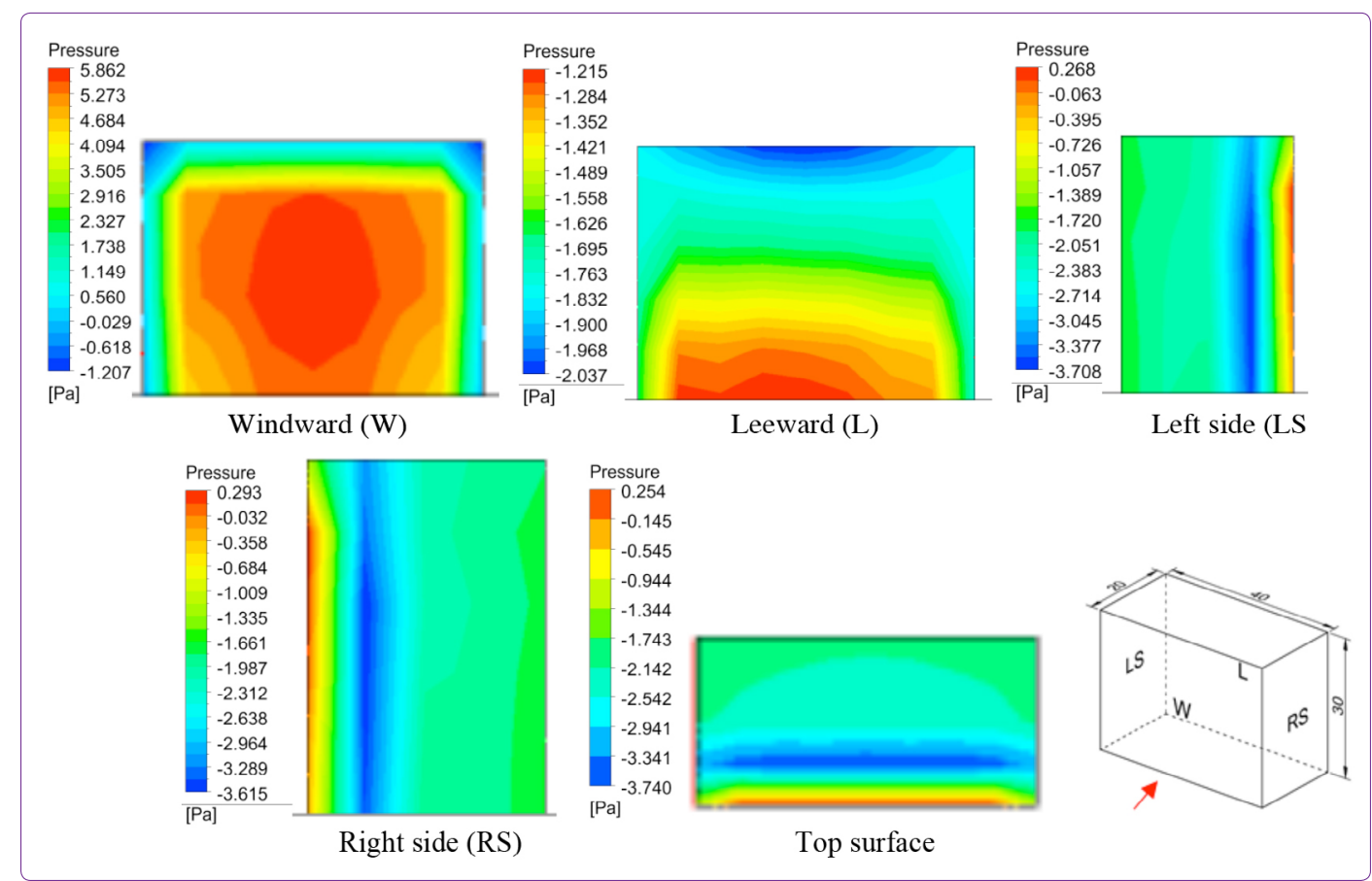

Figure 8. Wind pressure distributions on building surfaces for $\mathrm{D} 2$.

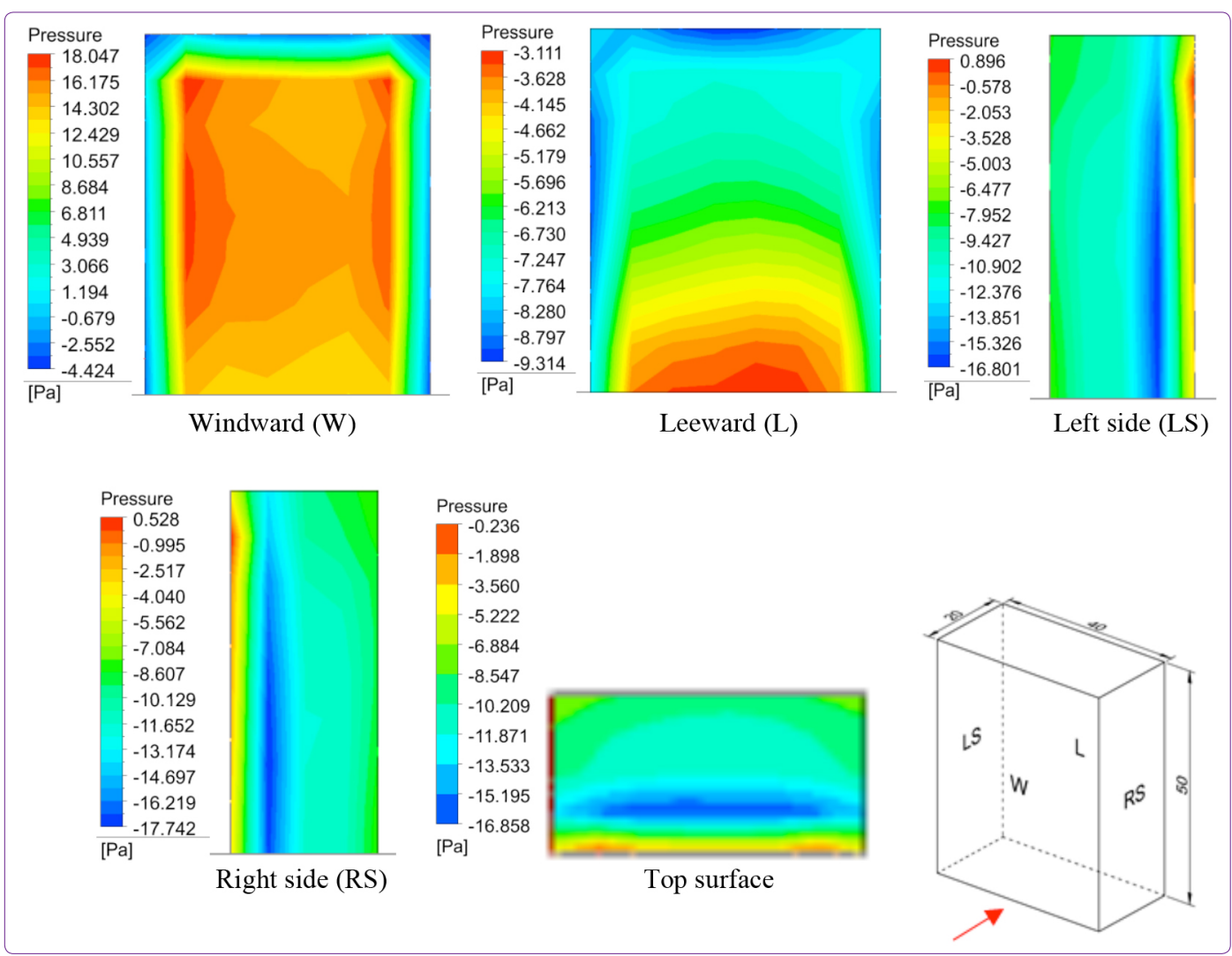

Figure 9. Wind pressure distributions on building surfaces for D3.

height. On the other hand, negative pressure values were observed on leeward and on both side surfaces (RS, LS). Besides, negative pressure values on the side surfaces are higher than negative pressure values on the leeward surface. There is considerable variation in the negative pressure values. On leeward surface, maximum negative forces were noticed at the corners of the building close to the building height. The negative pressure values tend 


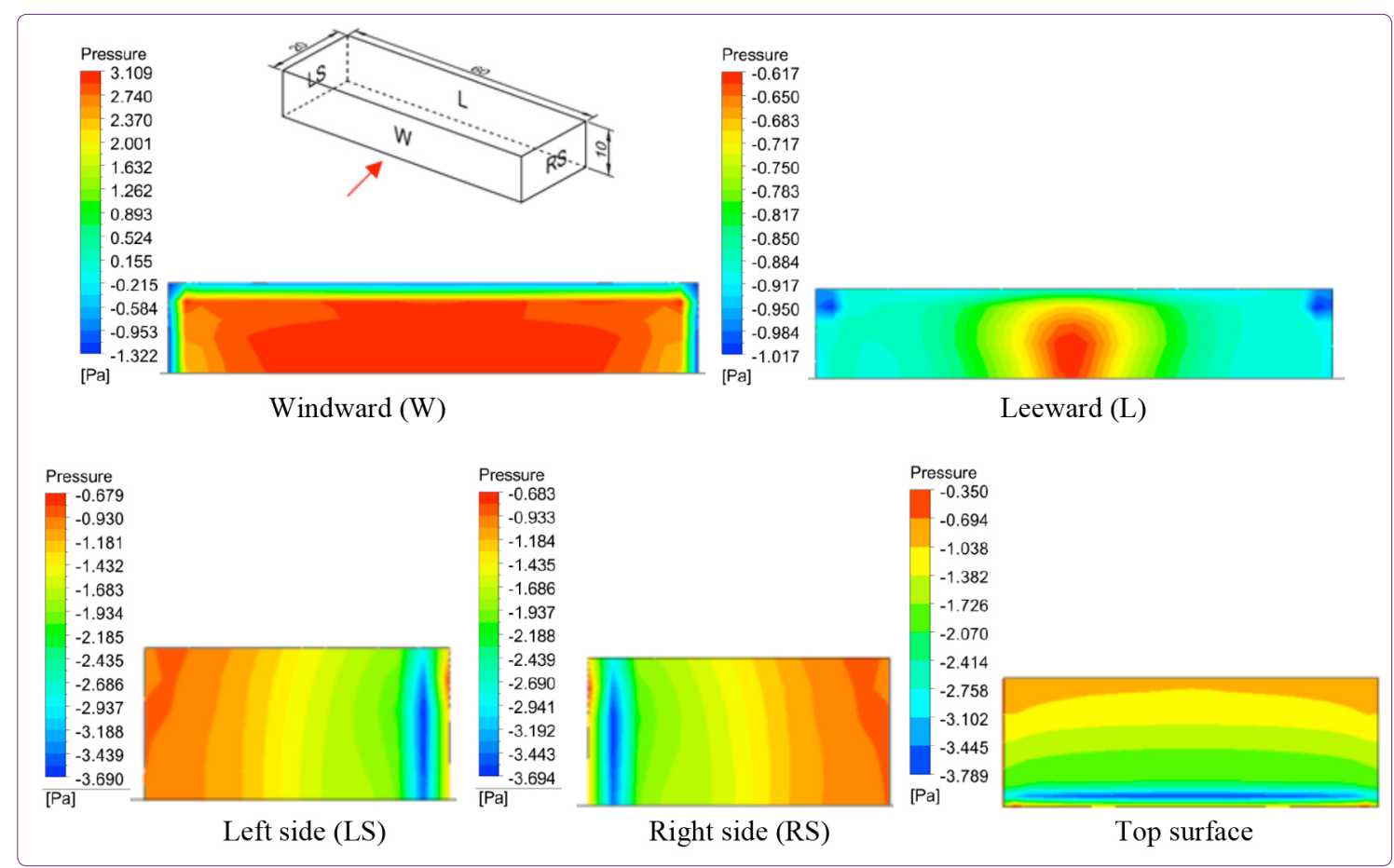

Figure 10. Wind pressure distributions on building surfaces for D4.

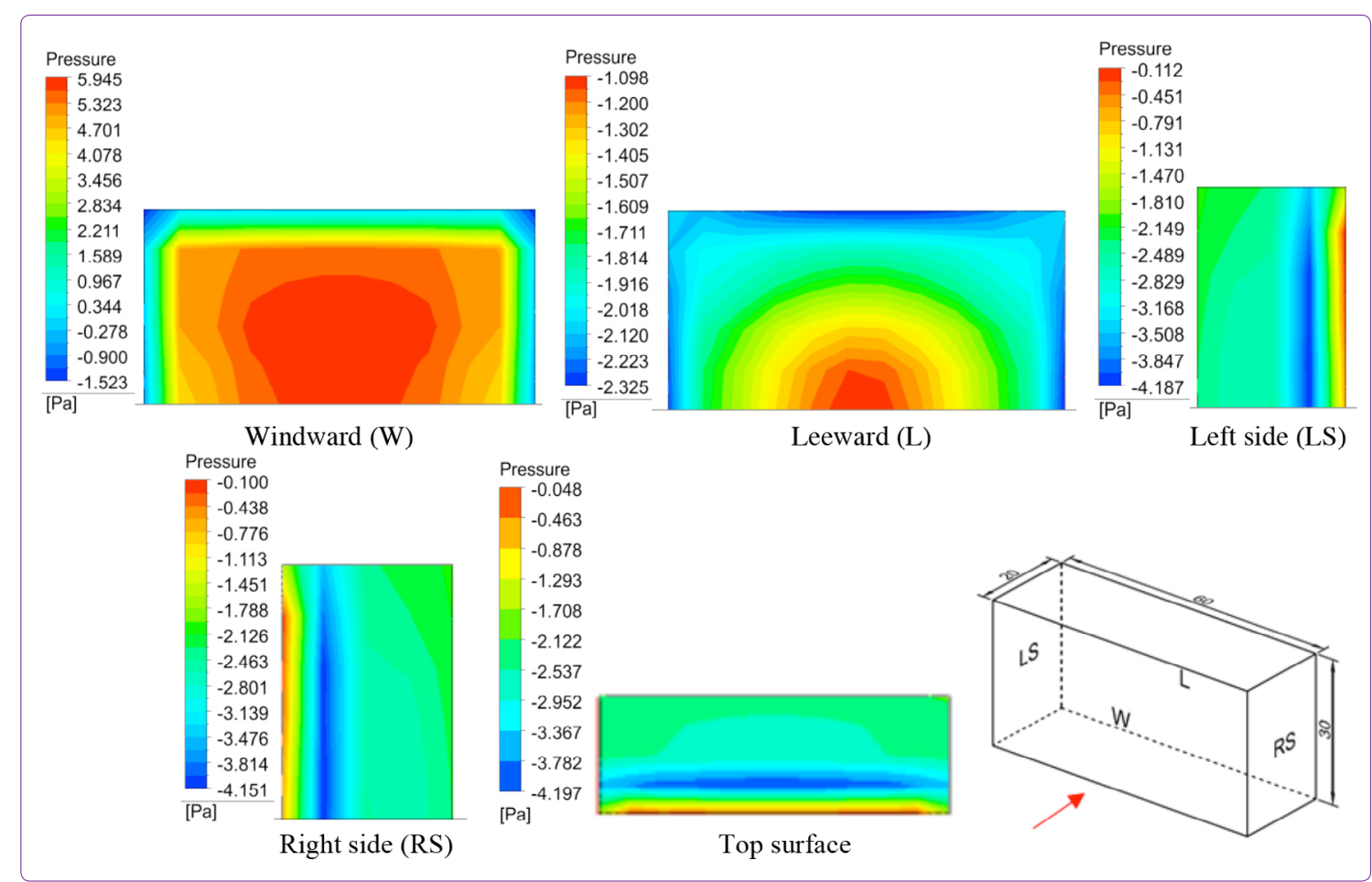

Figure 11. Wind pressure distributions on building surfaces for D5.

to decrease from windward to leeward on the top. While, maximum positive pressure on the windward surface of D4 was 3.10, absolute value of maximum negative pressure was 1.01 on leeward surface. On side surfaces, the absolute value of maximum negative pressure was 3.69. It was 3.78 in the top surface (Figure 10).
The model denoted as D5 is a rectangular plan shaped building with a height of $30 \mathrm{~m}$ and it is exposed to a wind velocity of $3 \mathrm{~m} / \mathrm{s}$. In D5 model, pressure coefficients take positive values on the windward surface and these positive pressure values varied greatly. On windward surface, pressure values did not increase along the height. 
Moreover, it tends to decrease both above the height level of $2 \mathrm{H} / 3$ and close to the side surfaces. Besides, the surface area affected by the pressure was expanded along the height and length on windward surface. Negative pressure values were observed on leeward and on both side surfaces (RS, LS). Negative pressure values on the side surfaces are seriously higher than negative pressure values on the leeward surface. In D5 model, while maximum positive pressure on the windward surface was 5.94, absolute value of maximum negative pressure was 2.32 on leeward surface. On side surfaces, the absolute value of maximum negative pressure was 4.18 . In top surface, the absolute maximum negative pressure was 4.19 (Figure 11).

The model denoted as D6 is a rectangular plan shaped building with a height of $50 \mathrm{~m}$ and it is exposed to a wind velocity of $5 \mathrm{~m} / \mathrm{s}$. In D6 model, pressure values take positive values on the windward surface and these positive pressure values varied greatly. On windward surface, pressure values did not display a regular increase or decrease along the height of the building. Besides, the surface area affected by the pressure was expanded along the height on windward surface. Moreover, on windward surface the positive pressure values decreased at a height close to the model height and on nearest to both side surfaces. On the other hand, negative pressure values were varied greatly. Negative pressure values were observed on leeward and on both side surfaces (RS, LS). Besides, negative pressure values on the side surfaces are considerably higher than negative pressure values on the leeward surface. In D6 model, while maximum positive pressure on the windward surface was 17.19 , absolute value of maximum negative pressure was 8.99 on leeward surface. On side surfaces, the absolute value of maximum negative pressure was 19.13. In top surface, the absolute maximum negative pressure was 18.95 (Figure 12).

Figure 13 shows the distribution of mean wind pressure coefficients $(C p)$ for various simple plan shaped buildings with various aspect ratios for different wind velocity, when surfaces are respectively sliced at $2 \mathrm{H} / 3, \mathrm{H} / 2$, and $\mathrm{H} / 3$.

In Figure 13, the mean $\mathrm{Cp}$ values of all surfaces were given for square plan shaped models $(K 1, K 2, K 3)$ designed at different wind velocity and heights. In all square models, pressure coefficients take positive values on the windward surface due to the pushing forces. Due to the flow separating from the side edges of the windward surface, negative peak pressure coefficient values occur in the separated flow regions on the side surfaces of windward. On the other hand, negative pressure coefficients were observed on leeward and on both side surfaces due to the suction forces (RS, LS). Besides, negative pressure values on the side surfaces are more critical than the negative pressure coefficients on the leeward surface.

In K1 model cp coefficients on windward surface did not increase along the height. On the contrary, cp coefficients on windward surface decrease close to the building height

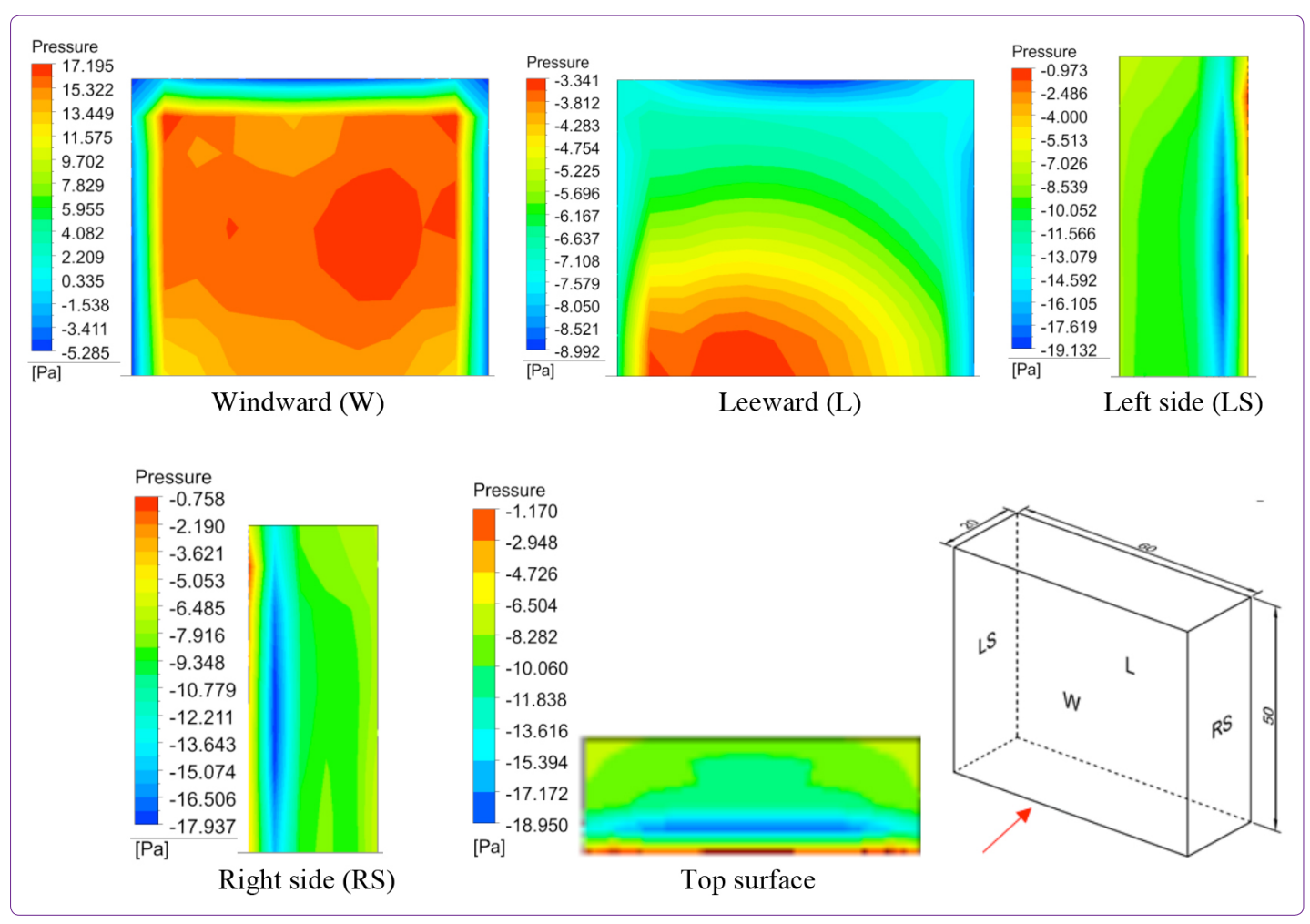

Figure 12. Wind pressure distributions on building surfaces for D6 
level $(2 \mathrm{H} / 3$ height level). It displays similar $\mathrm{cp}$ coefficients at $\mathrm{H} / 3$ and $\mathrm{H} / 2$ height level. On the other hand, on leeward surface, $c p$ coefficients behave an increase trend with the height. The increase or decrease of the height did not cause a significant change in the pressure coefficients on the both side surfaces. In K2 model, while positive pressure

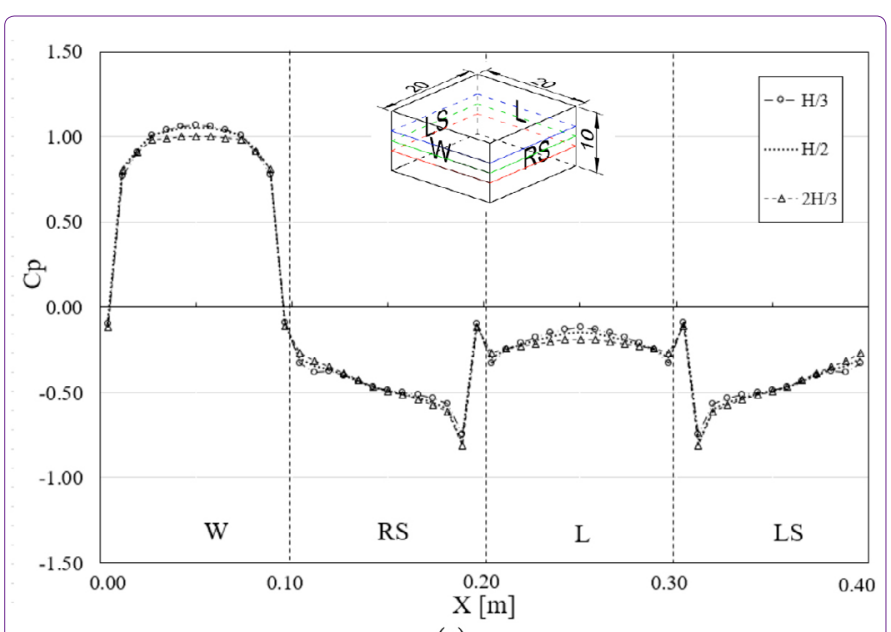

(a)

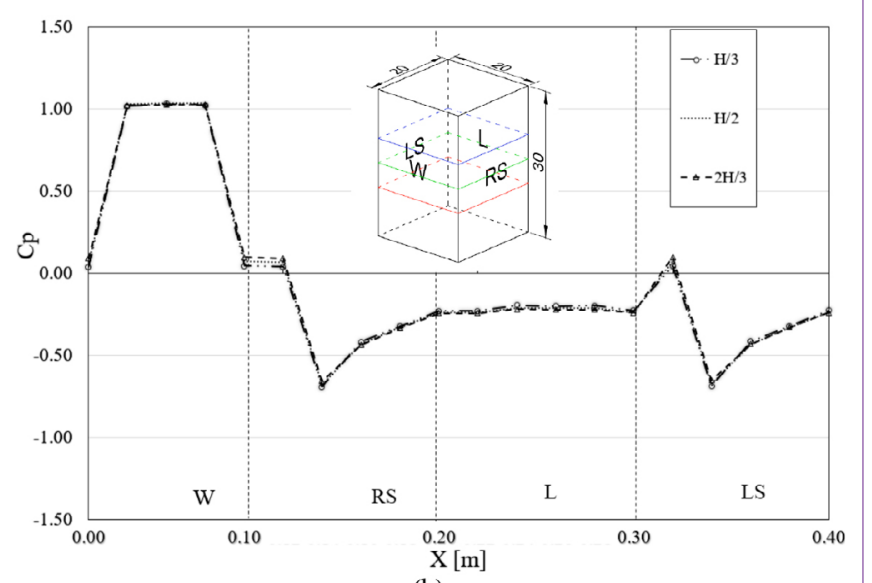

(b)

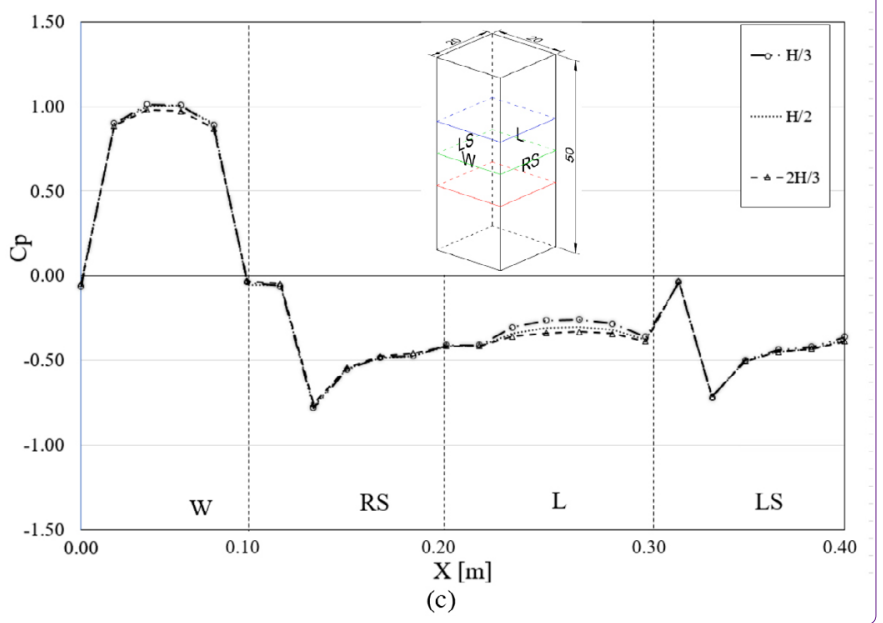

Figure 13. Pressure coefficients (a) K1, (b) K2, (c) K3. coefficients observed on the windward surface, negative pressure coefficients were noticed on leeward and on both side surfaces. The increase or decrease of the height did not cause a considerable change in the pressure coefficients on all surfaces. Pressure coefficients on all surfaces at almost all heights are close to each other. However, on leeward surface, a small increase was observed on cp coefficients with the close to the building height. In K3 model, positive pressure coefficients observed on the windward surface, negative pressure coefficients were noticed on leeward and on both side surfaces. Cp coefficients on windward surface did not increase along the height. On the contrary, $\mathrm{cp}$ coefficients on windward surface decrease close to the building height level $(2 \mathrm{H} / 3$ height level). It displays similar $\mathrm{cp}$ coefficients at $\mathrm{H} / 3$ and $\mathrm{H} / 2$ height level. On the contrary, on leeward surface, $\mathrm{cp}$ coefficients increase from the $\mathrm{H} / 3$ height level to $2 \mathrm{H} / 3$ height level. The increase or decrease of the height did not cause a significant change in the pressure coefficients on the both side surfaces.

In D1 model, positive pressure coefficients observed on the windward surface and negative pressure coefficients were noticed on leeward and on both side surfaces. Cp coefficients on windward surface decrease close to the building height. The increase or decrease of the height did not cause a significant change in the pressure coefficients on the both side surfaces and leeward surfaces (Figure 14).

In D2 model, while pressure coefficients on windward surface decrease along the height, they increase with the height on leeward surface. On both side surfaces, there is not a significant change in the pressure coefficients with the height.

In D3 model, positive pressure coefficients observed on windward surface, negative pressure coefficients were noticed on leeward and on both side surfaces. Pressure coefficients presents irregular values on windward surface. However, it displays a decrease trend with the height on windward surface. On the contrary, on leeward surface pressure coefficients increase with the height. It shows similar pressure coefficients on both side surfaces (Figure 14).

In D4 model pressure coefficients on windward surface did not decrease along the height. On the other hand, the increase or decrease of the height did not cause a significant change in the pressure coefficients on the both side surfaces and leeward surface. The model D4 has the greatest length ratio of 6.0. Therefore, the highest positive pressure coefficients on windward surface and the highest negative pressure coefficients on side surfaces were noticed (Figure 15).

In D5 model, positive pressure coefficients observed on the windward surface and negative pressure coefficients were noticed on leeward and on both side surfaces. While 


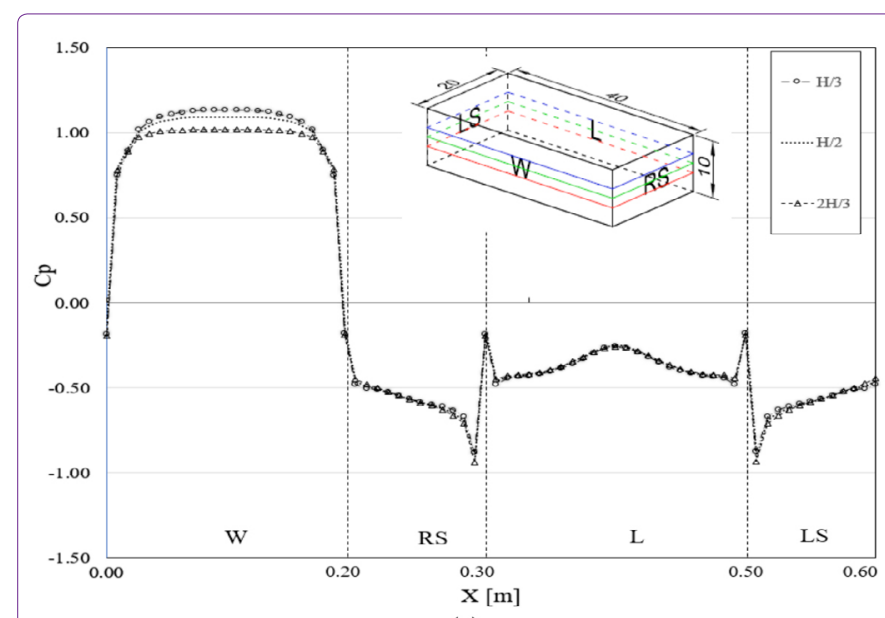

(a)

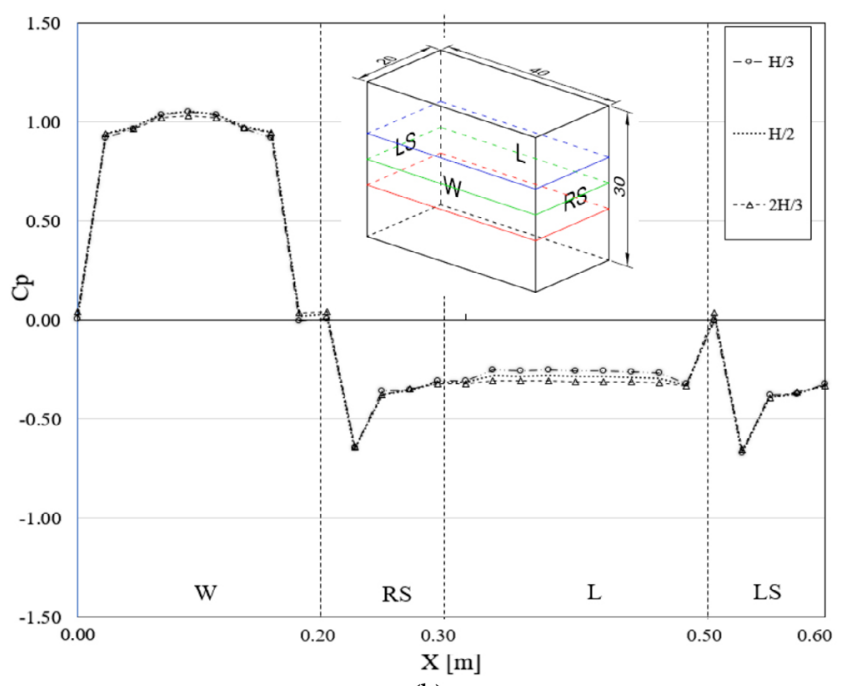

(b)

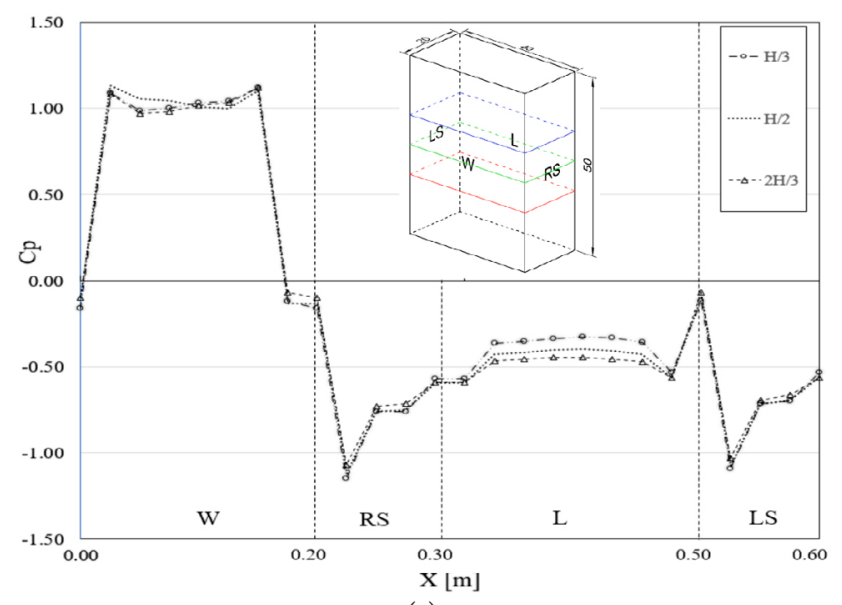

(c)

Figure 14. Pressure coefficients (a) D1, (b) D2, (c) D3.

pressure coefficients on windward surface decrease close to the building height, they increase with the height on leeward surface. The increase or decrease of the height did not cause a considerable change in the pressure coefficients on the both side surfaces.

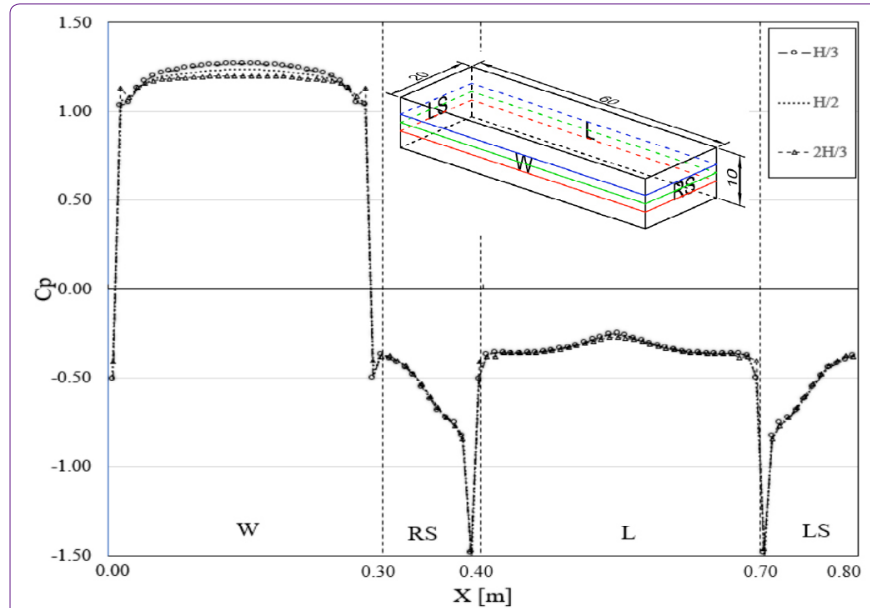

(a)

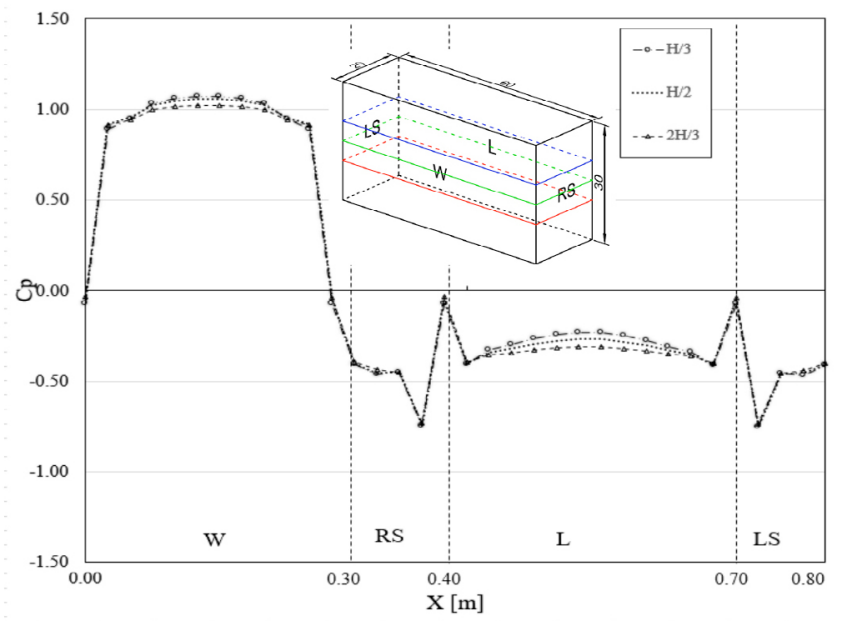

(b)

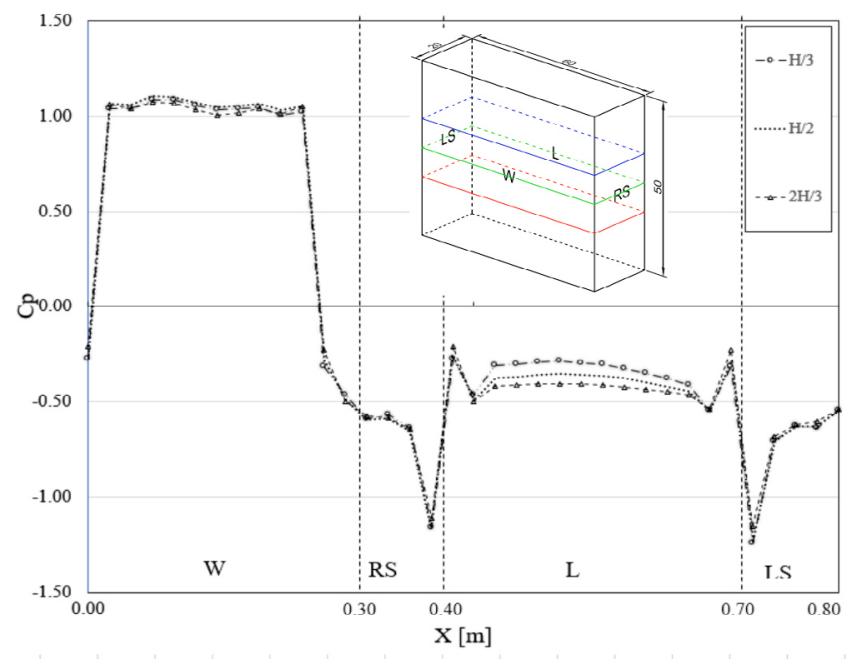

(c)

Figure 15. Pressure coefficients (a) D4, (b) D5, (c) D6.

In D6 model, while the highest positive pressure coefficients were observed at $\mathrm{H} / 2$ height level, the lowest ones were noticed at $2 \mathrm{H} / 3$ height level. On the other hand, the pressure coefficients increase with the height on leeward surface. Moreover, there is not a considerable 
change in the pressure coefficients on both sides. After the D4 model, the higher pressure values were noticed at side surfaces of D6 model (Figure 15).

When all models are compared, it is noticed that the pressure values increase significantly on all surfaces with the increase in height and wind velocity. For instance, while the maximum pressure value is 3.10 on windward surface of D4 model which has a $10 \mathrm{~m}$ height and exposing to $2 \mathrm{~m} / \mathrm{s}$ wind velocity, it is 17.19 in D6 model which has $50 \mathrm{~m}$ height and exposing $5 \mathrm{~m} / \mathrm{s}$ wind velocity. Besides, as width ratio (WR) and length ratio (LR) decreased and wind velocity increased it was observed that the pressure values on all surfaces increased in all models. The highest positive and negative pressure values are obtained on D6 model which has a $50 \mathrm{~m}$ building height and exposing $5 \mathrm{~m} / \mathrm{s}$ wind velocity. Therefore, as the building length and wind velocity increases, it has been realized that the pressure values on all surfaces generally increase.

\section{Wind Pressure Distributions Around Building Models}

To examine wind pressure distributions around buildings, models K1, D1 and D4 were chosen as in section 4.1. They were evaluated, at the height of $\mathrm{H} / 3, \mathrm{H} / 2,2 \mathrm{H} / 3$ and $\mathrm{Y} / 2$ levels.

In $\mathrm{K} 1$ and D1 model, while the positive pressure values around the buildings decrease, negative pressure values increase with the building height. On the other hand, while the positive pressure values around the D4 model decrease with the building height, negative pressure values increase from the height level $\mathrm{H} / 2$ to $2 \mathrm{H} / 3$. Positive and negative pressure values around the buildings increase from $\mathrm{K} 1$ model to D4 model. It can be concluded that pressure values around the buildings decrease with the narrower length (Figure 16-18).

Wind pressure values around the buildings increase from K1 model to D4 Model. Higher pressure region was

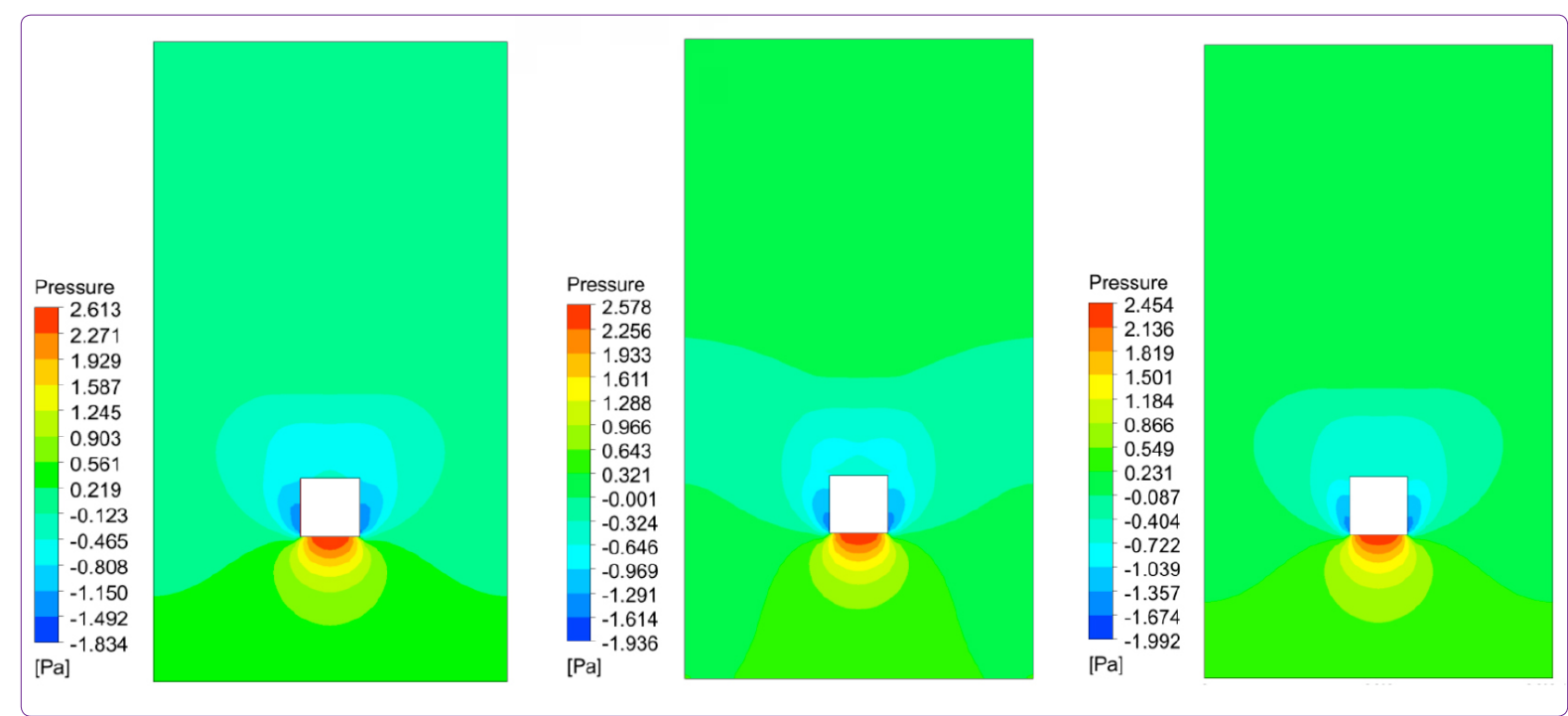

Figure 16. Wind pressure distributions around buildings for $K 1$ (a) $z=H / 3$, (b) $z=H / 2$ (c) $z=2 H / 3$.

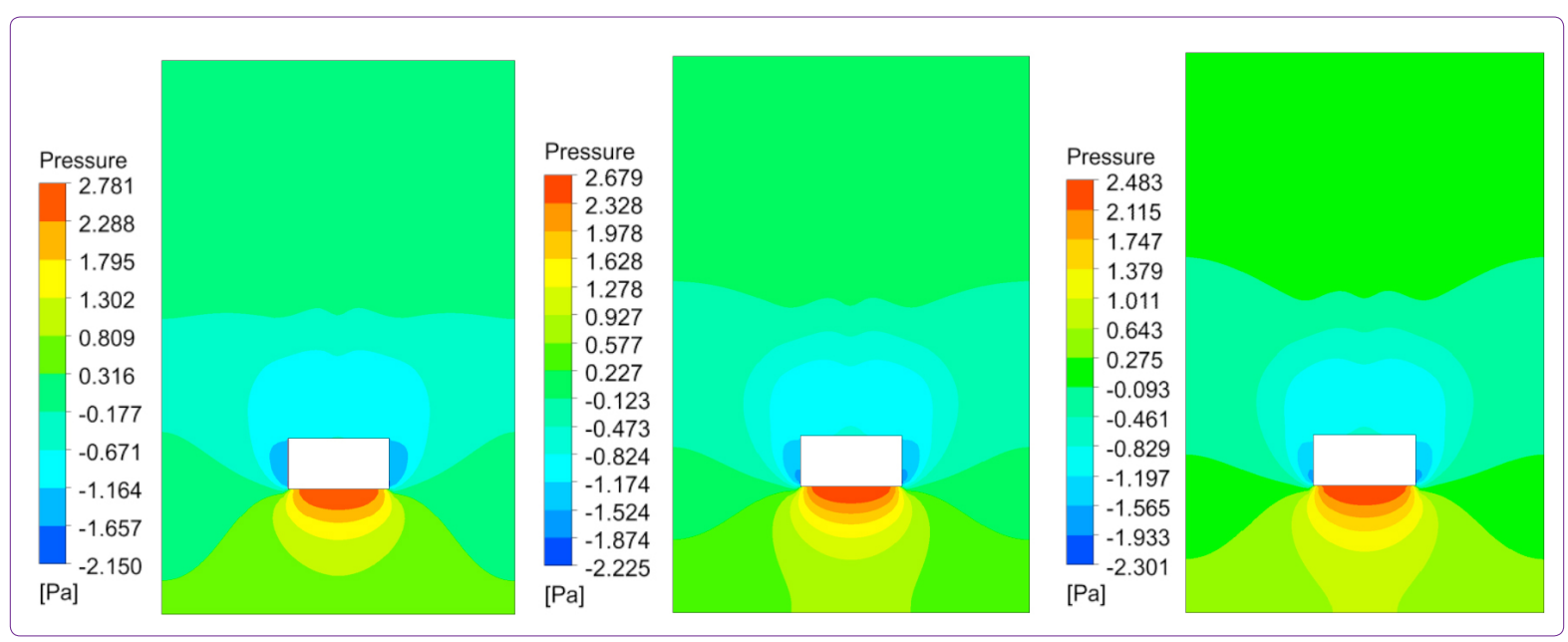

Figure 17. Wind pressure distributions around buildings for $D 1$ (a) $z=H / 3$, (b) $z=H / 2$ (c) $z=2 H / 3$. 


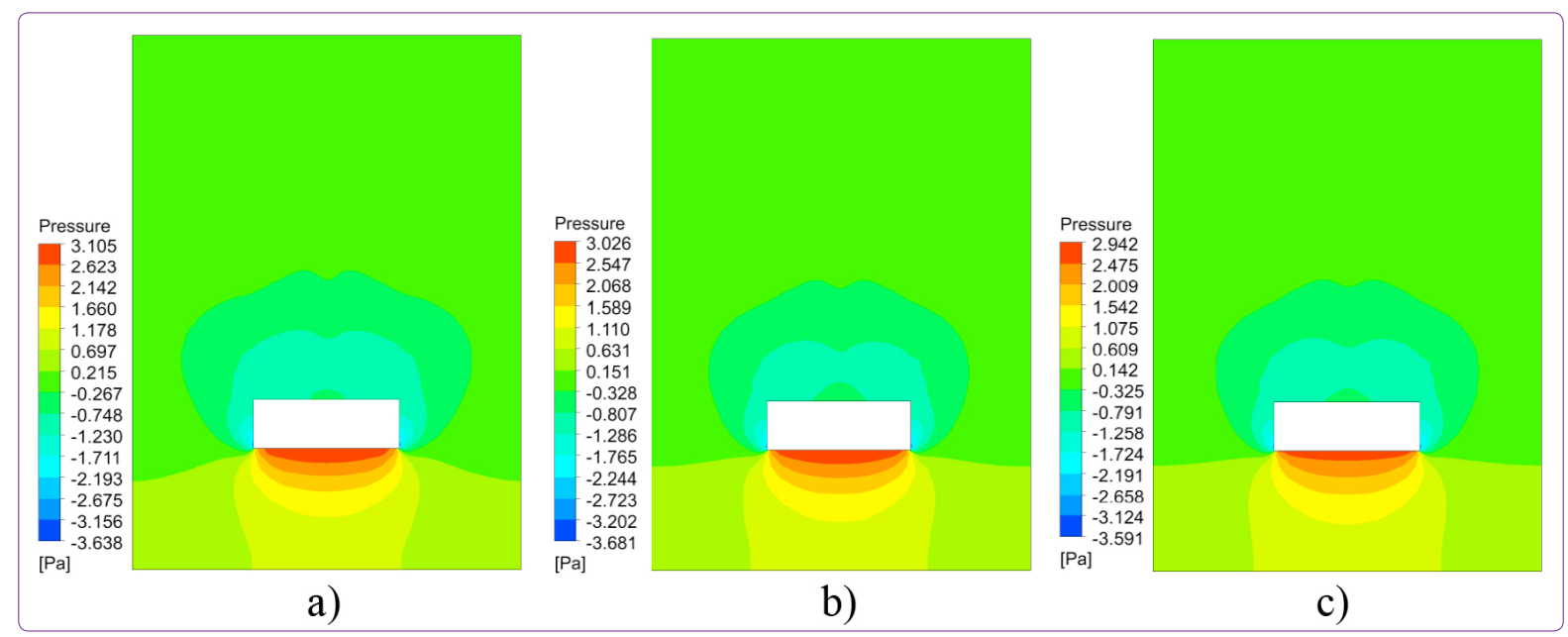

Figure 18. Wind pressure distributions around buildings for $D 4$ (a) $z=H / 3$, (b) $z=H / 2$ (c) $z=2 H / 3$.

observed around the D1 and D4 model than the K1 model (Figure 19).

When all models are compared, it is noticed that the pressure values around the buildings increase significantly with the increase in height level, building length and wind velocity. For instance, while a maximum pressure value of

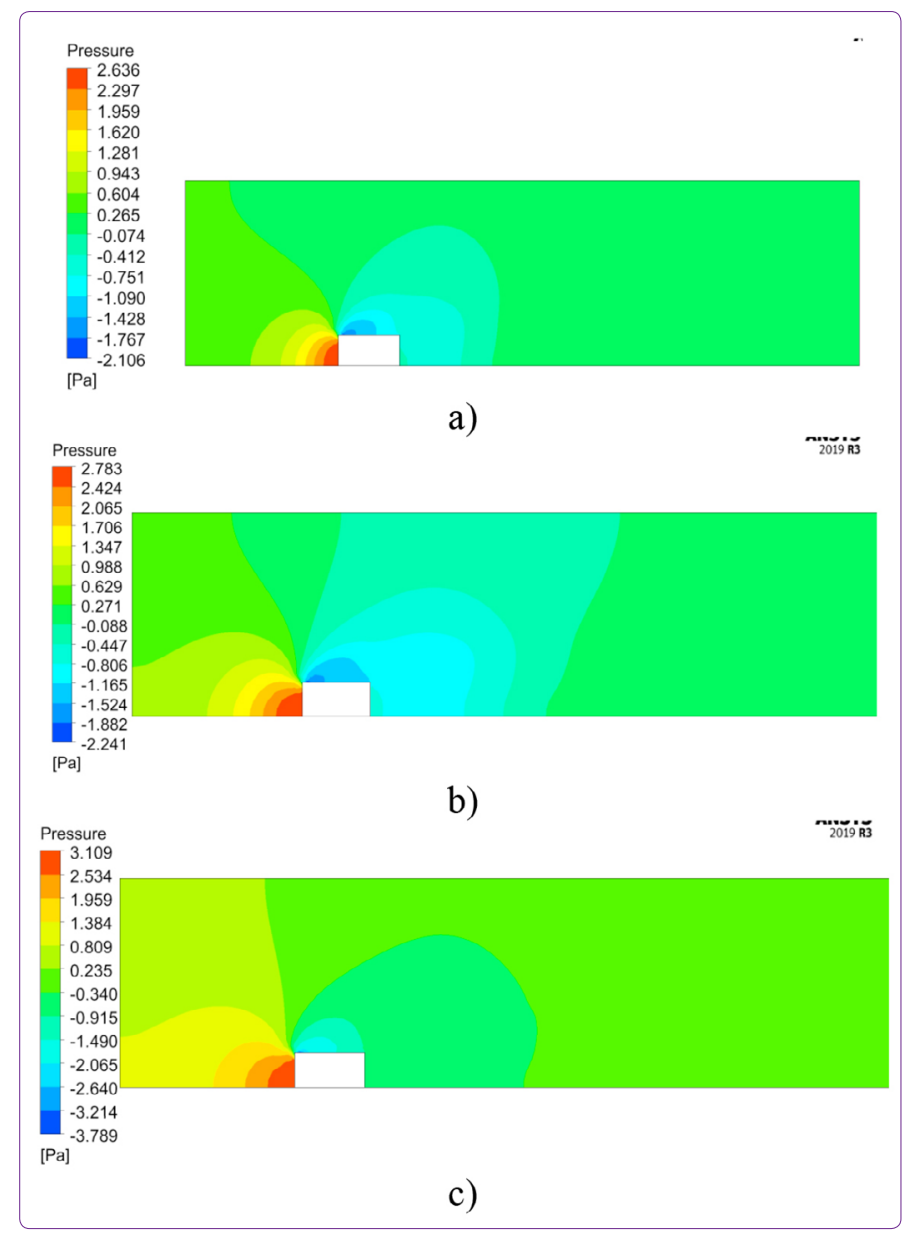

Figure 19. Wind pressure distributions around buildings at $Y / 2$ (a) $K 1$, (b) D1, (c) D4.
2.61 is observed for the $\mathrm{H} / 3$ level in square shaped model of K1 model, it is 3.105 for a rectangular shaped model of D4 model. When the models having the same width ratio (WR) K1, D1, D4 are compared, as the length increased and length ratio (LR) increased, pressure values increased around the building. Because, D4 has the highest length ratio among these models despite the same width ratio (WR). Therefore, it can be concluded that pressure region increase from square plan shaped building to rectangular plan shape building.

\section{Velocity Distributions}

Air flow generated by the wind are surrounded by building's side surfaces and perimeter via vortex clusters. Vortexes in general occurs in the region on side faces of the surface where the wind hits the building and in the region where the flow detachment. Therefore, dynamic loads created by vortexes are also variable direction and effects in the perpendicular to the wind flow direction.

A building can be accepted as an aerodynamically bluff body when flow streamlines do not follow the surface of the body similar to the case of streamlined body. However, it detaches from it leaving regions of separated flow and wide trailing wake. Flow behavior around the building models with the chosen velocity profile is shown in Figure 20.

When wind flow comes to the building the flow separated into two different regions as shown in Figure 20. In the nearest to those regions, high velocity flow can be observed. Leeward side of the building is generally in the wake where the lower negative pressure observed. This condition induces drag forces on the wall of the building in the leeward direction. Separated flows get reattached at rear stagnation point in the leeward direction of the building. The region between rear stagnation point and the building model is significantly turbulent and low in wind pressure. 


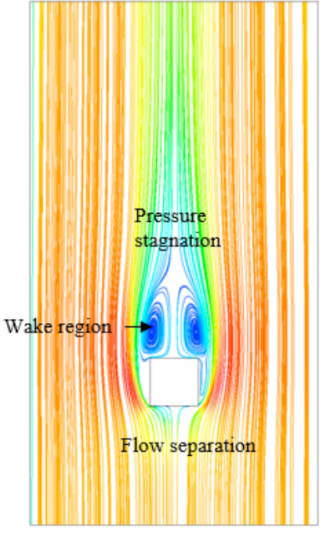

a)

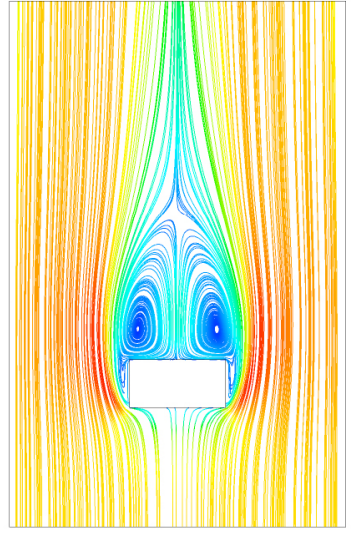

b)

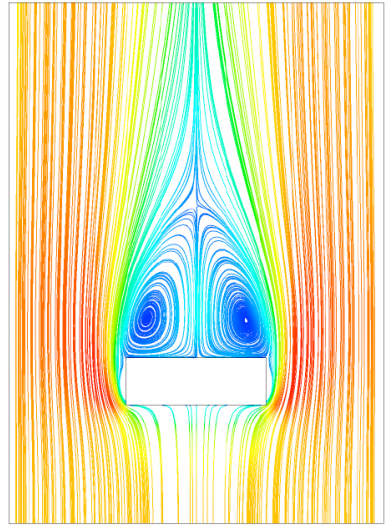

c)

Figure 20. Streamlines $\mathrm{z}=\mathrm{H} / 2$ (a) $\mathrm{K} 1$, (b) D1, (c) D4.

Wind flows around the different building forms for the wind velocity of $2 \mathrm{~m} / \mathrm{s}$ are presented in Figures 21-23. At the height of $\mathrm{z}=\mathrm{H} / 3$, turbulent flow is observed on the side surfaces of the all building models (RS, LS). Moreover, the velocity in the track zone decreases and reverse flow zones are formed. Maximum velocity occurs on the side surfaces of buildings. It is observed that the maximum velocity region on the side surfaces of the models expanded with increasing height. On the other hand, it is noticed that the drop in the velocity in the track region decreased with

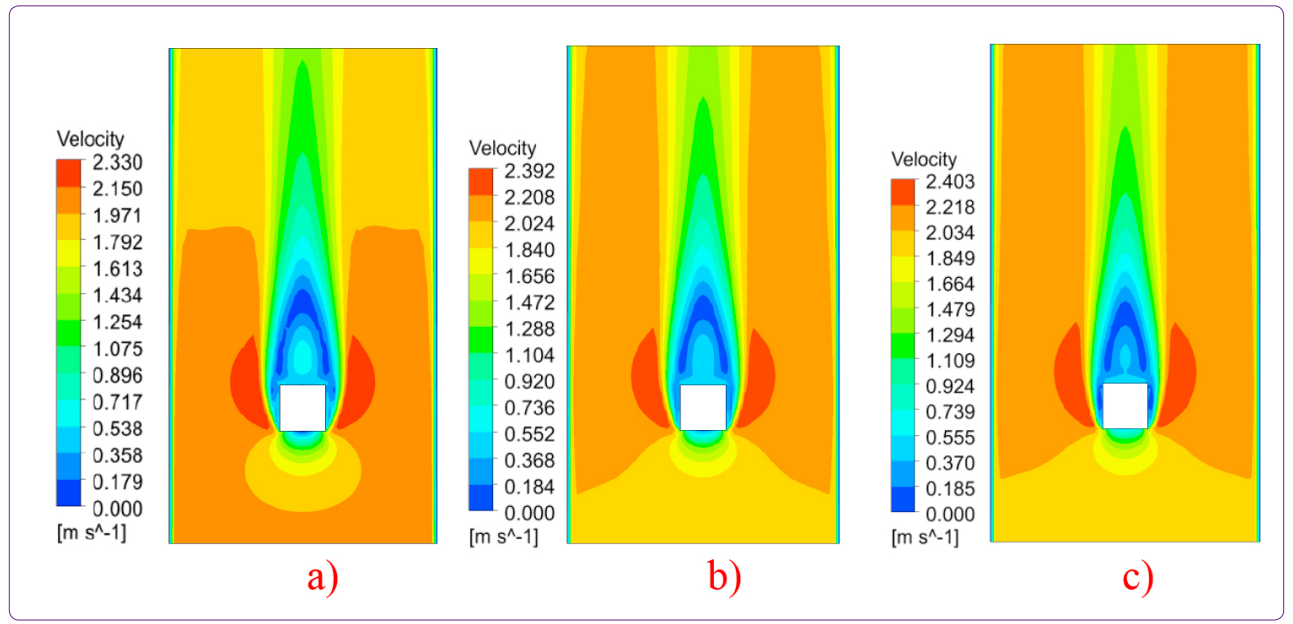

Figure 21. Velocity distributions around buildings for $K 1$ (a) $z=H / 3$, (b) $z=H / 2$ (c) $z=2 H / 3$.

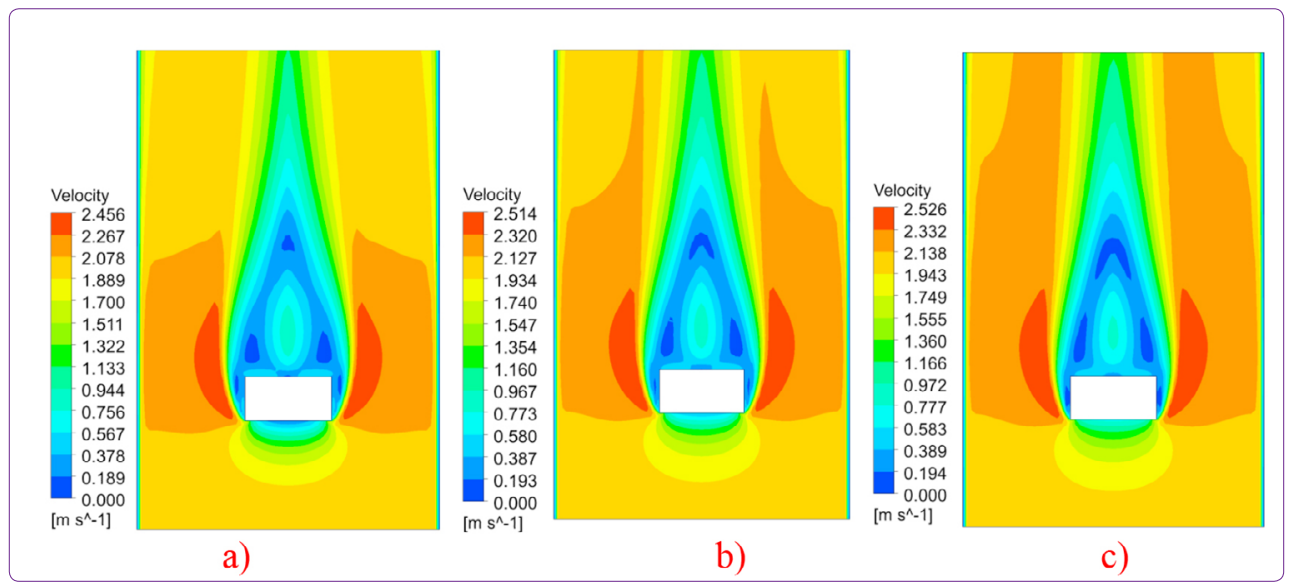

Figure 22. Velocity distributions around buildings for $D 1$ (a) $z=H / 3$, (b) $z=H / 2$ (c) $z=2 H / 3$. 


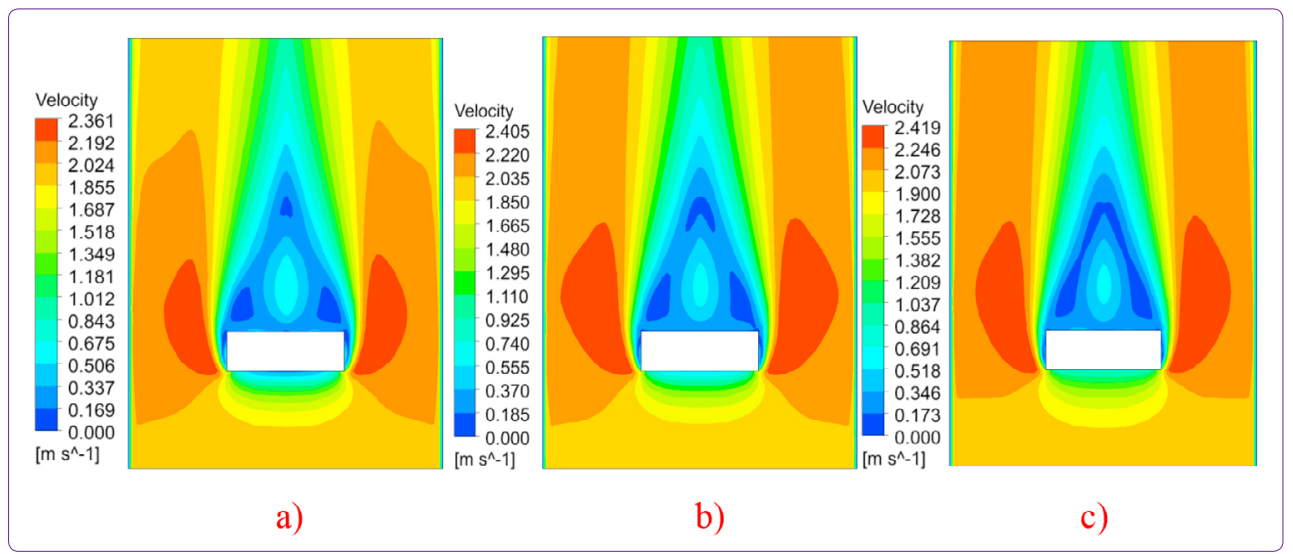

Figure 23. Velocity distributions around buildings for $D 4$ (a) $z=H / 3$, (b) $z=H / 2$ (c) $z=2 H / 3$.

increasing height. In the trace region, velocity decreases in all models. However, as the height of the model decreases, the velocity drops in the track zone increases. Otherwise, the velocity region increases from square shaped building to rectangular shaped building.

When all models are compared in terms of wind velocity distributions, it is noticed that the maximum velocity occurs on the side surfaces of building models and the velocity region on the side surfaces in all models expanded with an increase in height level. Moreover, the elongation in the building length creates an increase in the velocity region. Therefore, it can be concluded that velocity region increase from square shaped model to rectangular shaped models and with the increase in height level.

\section{Conclusions}

In this study, various simple plan shaped buildings with different aspect ratios were analyzed under various wind velocity to examine wind pressure distributions, and velocity distributions on and around the building. With this aim, ANSYS Fluent 20.0 Computational Fluid Dynamics (CFD) software package program is used for the analysis. The flow is considered as steady, fully turbulent and three dimensional. From the study broad conclusions were obtained. Results indicated that various phenomena such as plan geometry, aspect ratios, storey height were significant on wind pressure distributions, and velocity distributions on and around the building.

When the models were investigated, it was realized that positive and negative pressure distributions varied greatly from the value of 2.00 to 19.13 . In all building models, the pressure coefficients have positive values due to the pushing effect on the windward surface which is directly exposed to the wind. Due to the flow leaving the upper edge of the windward surface of the building, a negative pressure region formed on the top of the building and on leeward surface. Critical negative pressures occur at the region where flow leave the front edge of the top region.
In all building models, the most critical negative pressure coefficients were noticed on side surfaces.

According to plan geometry, it can be concluded that side surfaces (including RS and LS) were prone to expose to higher wind pressures, when windward surfaces were wider. In other words, as the length of the building increased, the pressure values increased on the side surfaces. For instance, a squared model of K1 model takes 2.00 pressure value on side surfaces, a rectangular model of D6 model which has the highest length takes 19.13 pressure value on that surfaces. When the pressure coefficients on the leeward surface of the building models were evaluated, it was observed that the change in the plan shape did not have a significant effect on pressure coefficients on leeward surface. However, the change on the plan shape or variation in the aspect ratios and wind velocity have critical effects in the pressure coefficients on side surfaces. Positive pressure values are higher than negative pressure values in all $\mathrm{K}$ models. Positive and negative pressure values around the buildings increase from squared model K1 model to rectangular model D4. It can be concluded that pressure values around the buildings decrease with the shortening in length.

When the impacts of aspect ratios on pressure coefficients were evaluated, it was noticed that the most critical pressure coefficients were observed on windward surface and on the side surfaces. It is realized that as the width ratio (WR) and length ratio (LR) decreased and wind velocity increased the pressure values on all surfaces increased in all models. The highest positive and negative pressure values are obtained on rectangular shaped model of D6 exposing $5 \mathrm{~m} / \mathrm{s}$ wind velocity which has the lowest width ratio (WR) and length ratio (LR). While D6 model takes 17.19 pressure values on windward surface and -19.13 on side surfaces, the squared mode K1 which has the highest ratios and lowest wind velocity of $2 \mathrm{~m} / \mathrm{s}$ takes the lowest pressure values of 2.63 pressure value on windward surface and -2.00 on side surfaces. 
Therefore, it can be concluded that if the aspect ratios decrease and building length, building height and wind velocity increase, the pressure values on all surfaces increase in general.

Based on the wind velocity, maximum velocity occurs on the side surfaces of buildings. It is observed that the maximum velocity region on the side surfaces of the models expanded with increasing height. In the trace region, velocity decreases in all models. Besides, the elongation in the building length creates an increase in the velocity region. Therefore, it can be concluded that velocity region increase from square shaped model to rectangular shaped models and with the increase in height level.

Extensive inferences have been made by comparing models with the same characteristics. When the models K1, D1 and D4 having the same height, same wind velocity, and also the same width ratio (WR) were examined, it is noticed that the positive pressure values on the windward surface and negative pressure values on side surfaces increase with the increase in the length ratio. On the other hand, the model D1 having length ratio (LR) of 4 takes higher negative pressure coefficients than the model K1 on leeward surface. However, the model D4 having a LR of 6 takes higher negative pressure values than the K1 model, it decreases compared to D1. In K1 model, positive pressure values decreased in the windward surface with an increase in building height, while an increase was observed in the leeward. There is not a significant difference on side surfaces.

When the models K2, D2 and D5 having the same height, same wind velocity, and also the same width ratio of $2 / 3$ (WR) were evaluated, it is noticed that the positive pressure values on the windward surface and negative pressure values on leeward surface increase with the increase in the length ratio. D2 model with a LR value of 1.33 takes lower negative pressure coefficients on side surfaces than the model K2 with a LR of 0.66 . On the other hand, D5 model with a LR value of 2.00 takes higher negative pressure values than the model $K 2$.

When the models K3, D3 and D6 having the same height, same wind velocity, and also the same width ratio (WR) were investigated, it is realized that negative pressure values on the side surfaces increased as LR increased. The model D3 takes higher positive and negative pressure coefficients than the model K3. On the other hand, although the model D6 with a LR value of 1.20 takes higher pressure values than the model $\mathrm{K} 3$, there was a small decrease in positive pressure values on windward surface and negative pressure values in Leeward compared to D3 model. In conclusion, aspect ratios and wind interaction has been found to be effective in the pressure distribution on and around the building. In general, conclusions obtained in this study can assist architects and architectural students to use in their architectural design process as a design assistance tool.

\section{References}

Ahmad, S., \& Kumar, K. (2002). Effect of Geometry on Wind Pressures on Low-Rise Hip Roof Buildings. Journal of Wind Engineering and Industrial Aerodynamics, 90(7), 755-779. https://doi.org/10.1016/S0167-6105(02)00152-6

Aygün, C., \& Başkaya, ş. (2003). Çok Katlı Bir Bina Etrafindaki Rüzgar Akışının Oluşturduğu Yüzey Basınçlarının Deneysel Olarak İncelenmesi. Gazi Ünivesitesi Mühendislik Mimarlık Fakültesi Dergisi, 18(4), 15-31.

Bairagi, A.K., \& Dalui, S.K. (2020). Distribution of Wind Pressure Around Different Shape Tall Building. In M. Vinyas et al. (Eds.), Advances in Structures, Systems and Materials (31-38). Springer Nature Singapore Pte Ltd. https://doi. org/10.1007/978-981-15-3254-2_4

Becker, S., Lienhart, H., \& Durst, F. (2002). Flow around threedimensional obstacles in boundary layers. Journal of Wind Engineering and industrial aerodynamic, 90(4-5), 265-279. https://doi.org/10.1016/S0167-6105(01)00209-4

Bhattacharyya, B., \& Dalui S.K. (2018). Investigation of mean wind pressures on ' $\mathrm{E}$ ' plan shaped tall building. Wind and Structures, 26(2), 99-114. http://dx.doi.org/10.12989/ was.2018.26.2.099

Blocken, B., Carmeliet, J., \& Stathopoulos, T. (2007). CFD Evaluation of the Wind Speed Conditions in Passages between Buildings-Effect of Wall-function Roughness Modifications on the Atmospheric Boundary Layer Flow. Journal of Wind Engineering and Industrial Aerodynamics, 95 (9-11), 941962. https://doi.org/10.1016/j.jweia.2007.01.013

Blocken, B. (2015). Computational fluid dynamics for urban physics: Importance, scales, possibilities, limitations and ten tips and tricks towards accurate and reliable simulations, Building and Environment, 91, 219-245. https://doi.org/10.1016/j.buildenv.2015.02.015

Fertelli, A.,\& Balta, M. (2017). Tek ve İki Bina Etrafindaki Rüzgar Etkilerinin Sayısal Olarak İncelenmesi. Çukurova University Journal of the Faculty of Engineering and Architecture, 32 (3), 111-119.

Franke, J. (2006). Recommendations of the Cost Action C14 on the use of CFD in Predicting Pedestrian Wind Environment. 4th International Symposium on Computational Wind Engineering, Japan Association for Wind Engineering, Yokohama, 529-532.

Gölbaşı, D., Buyruk, E., \& Şahin, B. (2015). Farklı Geometrilere Sahip Olan Binalarda Akış Yapılarının Sayısal ve Deneysel Olarak Incelenmesi. TMMD Dergisi, 46-55.

Hasol, D. (1994). Japonya'dan İzlenimler. Yapı Dergisi, 150, 46-57.

He, B.J., Yang, L., \& Ye, M. (2014). Strategies for creating good wind environment around Chinese residences. Sustainable Cities and Society, 10, 174-183. https://doi.org/10.1016/j. scs.2013.08.003

Holmes, J.D., Tamura, Y., \& Krishna, P. (2008). Wind Loads on Low, Medium and High Rise Buildings by Asia-Pacific Codes. The 4th International Conference on Advances in Wind and Structures, Jeju, Korea, 73-90, 
Huang, P., Luo, P., \& Gu, M. (2005). Pressure and forces measurements on CAARC standard Tall building in wind tunnel of Tong Ji University. In Proceedings of the 12th national wind engineering conference of China, Xi'an, China, 240-244.

Karadağ, i.., \& Serteser, N. (2019). Rüzgar-Yapı Etkileşiminin Ön Tasarım Aşamasında Tahminine Yönelik Bir Algoritma, Megaron, 14 (2), 205-212. https://doi.org/10.14744/ MEGARON.2018.37167

Kim, Y.C., Yoshida A., \& Tamura Y. (2012). Characteristics of surface wind pressures on low-rise building located among large group of surrounding buildings. Engineering Structures, 35, 18-28. https://doi.org/10.1016/j.engstruct.2011.10.024

Li, Y., Duan, R.B., Li, Q.S., Li, Y.G., \& Li, C. (2020). Research on the characteristics of wind pressures on L-shaped tall buildings. Advances in Structural Engineering, 23 (10), 2070-2085. https://doi.org/10.1177/1369433220906934

Liu, Z., Yu, Z., Chen, X., Cao, R., \& Zhu, F. (2020). An investigation on external airflow around low-rise building with various roof types: PIV measurements and LES simulations. Building and Environment, 169, 1-20. https://doi.org/10.1016/j. buildenv.2019.106583

Mallick, M., Kumar, A., \& Patra, K.C. (2019). Experimental Investigation on the Wind-Induced Pressures on C-Shaped Buildings. Journal of Civil Engineering, 23 (8), 3535-3546. https://doi.org/10.1007/s12205-019-1929-6

Montazeri, H., \& Blocken, B. (2013). CFD simulation of wind induced pressure coefficients on buildings with and without balconies: validation and sensitivity analysis, Building and Environment, 60, 137-149. https://doi.org/10.1016/j. buildenv.2012.11.012

Mou, B., He, B.J., Zhao, D.X., Chau, \& K.W. (2017). Numerical simulation of the effects of building dimensional variation on wind pressure distribution. Engineering Applications of Computational Fluid Mechanics, 11 (1), 293-309. https://doi. org/10.1080/19942060.2017.1281845

Ok, V. (2010). Sağlıklı Kentler İçin Pasif Iklimlendirme ve Bina Aerodinamiği.Tesisat Dergisi, 103, 33-40.

Patankar, S. (1980). Numerical Heat Transfer and Fluid Flow. Taylor \& Francis Group, Hemisphere, Washington, D.C.
Roberson, J.A., Crowe, \& C.T. (1978). Pressure Distribution on Model Buildings at Small Angles of Attack in Turbulent Flow. Proc. 3rd U.S. Natl. Conf. on Wind Engineering Research, University of Florida, 28-41.

Şabanoğlu, Ö., \& Çağdaş, G. (2019). Toplu Konut Yerleşimlerindeki Açık Alanlarda Rüzgarın Kullanıcı Konforuna Etkisinin Analizi ve Değerlendirilmesi. Megaron, 14 (Suppl. 1), 53-69. https:// doi.org/10.5505/MEGARON.2018.91668

Tominaga, Y., Mochida, A., Yoshiec, R., Kataokad, H., Nozue, T., Yoshikawa, M., \& Shirasawa, T. (2008). AlJ Guidelines for Practical Applications of CFD to Pedestrian Wind Environment around Buildings. Journal of Wind Engineering and Industrial Aerodynamics, 96(10-11), 1749 - 1761. https://doi. org/10.1016/j.jweia.2008.02.058

Tong, Z., Chen, Y., Malkawi, A., Adamkiewicz, G., \& Spengler, J.D. (2016). Quantifying the impact of traffic-related air pollution on the indoor air quality of a naturally ventilated building. Environment International, 89, 138-146. https:// doi.org/10.1016/j.envint.2016.01.016

Uematsu, Y., \& Isyumov, N. (1999). Wind pressures acting on low-rise buildings. Journal of Wind Engineering and Industrial Aerodynamics, 82(1-3), 1-25. https://doi.org/10.1016/ S0167-6105(99)00036-7

Weerasuriya, A.U. (2013). Computational Fluid Dynamic (CFD) Simulation of Flow around Tall Buildings. Engineering, 46(3), 43-56. https://doi.org/10.4038/engineer.v46i3.6784

Xu, X., Yang, Q., Yoshida, A., \& Tamura, Y. (2017). Characteristics of pedestrian-level wind around super-tall buildings with various configurations. Journal of Wind Engineering and Industrial Aerodynamics, 166, 61-73. https://doi.org/10.1016/j.jweia.2017.03.013

Zhao, D.X. He, \& B.J. (2017). Effects of architectural shapes on surface wind pressure distribution: case studies of ovalshaped tall buildings. Journal of Building Engineering, 12, 219-228. http://dx.doi.org/10.1016/j.jobe.2017.06.009

Zhao, Z.Q., He, B.J., Li, L.G., Wang, H.B., \& Darko, A. (2017). Profile and concentric zonal analysis of relationships between land use/land cover and land surface temperature: case study of Shenyang, China. Energy and Buildings, 155, 282-295. https://doi.org/10.1016/j.enbuild.2017.09.046 